\title{
The Padul mammoth finds - On the southernmost record of Mammuthus primigenius in Europe and its southern spread during the Late Pleistocene
}

\author{
Diego J. Álvarez-Lao ${ }^{\mathrm{a}, *}$, Ralf-Dietrich Kahlke ${ }^{\mathrm{b}}$, Nuria García ${ }^{\mathrm{c}, \mathrm{d}}$, Dick Mol ${ }^{\mathrm{e}}$ \\ a Departamento de Geología, Universidad de Oviedo, C/ Jesús Arias de Velasco s/n 33005 Oviedo, Spain \\ b Senckenberg Research Institutes, Research Station of Quaternary Palaeontology Weimar, Am Jakobskirchhof 4, D-99423 Weimar, Germany \\ c Departamento de Paleontología, Universidad Complutense de Madrid, Facultad de Ciencias Geológicas, Ciudad Universitaria s/n, 28040 Madrid, Spain \\ d Centro (Universidad Complutense de Madrid-Instituto de Salud Carlos III) de Evolución y Comportamiento Humanos, C/ Sinesio Delgado 4, Pabellón 14, 28029 Madrid, Spain \\ e Natural History Museum Rotterdam, P.O. Box 23452, NL-3001 KL Rotterdam, The Netherlands
}

\section{A R T I C L E I N F O}

\section{Article history:}

Received 20 January 2009

Received in revised form 8 April 2009

Accepted 13 April 2009

\section{Keywords:}

Late Pleistocene

Mammuthus primigenius

Palaeobiogeography

Holarctic

Southern Spain

\begin{abstract}
A B S T R A C T
Fossil remains of at least four mature to old mature male individuals of Mammuthus primigenius have been discovered in a peat-bog of Late Pleistocene age, situated near to the town of Padul in the Granada Basin (Southern Spain). Radiocarbon dates indicate the presence of woolly mammoth in Southern Spain between 35.8 and $25.7 \mathrm{ka}$ BP (40.4-30.6 cal ka BP), a time span corresponding with the later part of MIS 3. The Padul mammoths did not differ morphometrically from individuals of contemporaneous populations of other European regions, but represent the westernmost portion of an extended and continuous Holarctic belt of mammoth distribution. The area immediately northwest of the Pyrenees including a slender belt of dry land along the coast of the Bay of Biscay is considered the immigration route of $M$. primigenius into the Iberian Peninsula. The southernmost extent of Iberian woolly mammoths correlates with periods of particularly dry and cold climatic conditions, where they are documented in terrestrial and marine sediment sequences of the region.

The southern expansion of M. primigenius during the Late Pleistocene extended to similar latitudes in Europe, Asia and North America, paralleling the distribution of suitable steppe- or tundra-steppe like environments. The woolly mammoth's southernmost advances were limited by the vegetational character of corresponding landscapes, by the configuration of marine shore lines and high mountain chains and by the extension of semideserts and deserts. Phases of mammoth dispersal into the Iberian and Italian Peninsulas during the later part of MIS 3 and early MIS 2 can be roughly correlated with the southern distribution of the species in the eastern Palaearctic. Along the eastern coast of the Pacific Ocean, the topography and glaciation of the Rocky Mountains range prevented a similar dispersal of woolly mammoths into western North America. The expansion of Late Pleistocene M. primigenius within the inner-continental areas of Eurasia and North America differs chronologically from those at the continental margins.
\end{abstract}

(c) 2009 Elsevier B.V. All rights reserved.

\section{Introduction}

Late Pleistocene remains of Mammuthus primigenius belong to the most common fossil finds in middle and northern latitudes of Eurasia as well as of North America. The abundance of sites permits the identification of the geographic range of $M$. primigenius during the Last Glacial (Eurasia: Kahlke, 1999; Kahlke and Mol, 2005; North America: Agenbroad, 1985, 1989; Agenbroad et al., 1994; Graham and Lundelius, 1994), encompassing more than $270^{\circ}$ of longitude and a maximum of $45^{\circ}$ of latitude, stretching from the Iberian Peninsula, the British Isles and Scandinavia in the West via central and eastern Europe, the Urals, western and eastern Siberia up to Yakutia, and the shelf regions of the extant Arctic Ocean and Beringia into of North America. Hundreds of thousands of woolly mammoth remains have been recovered from this

\footnotetext{
* Corresponding author. Tel.: + 34 985565435; fax: +34 985103103

E-mail address: dalao@geol.uniovi.es (D.J. Álvarez-Lao).
}

area. In the epicontinental North Sea basin alone, some 50,000 Late Pleistocene molars have been found by fishermen dredging for flatfish during the last century (estimation by D. Mol in Kahlke (2001)). In contrast, so far only $25 \mathrm{M}$. primigenius fossil localities have been reported from the Iberian Peninsula. The small number of recorded sites indicates a discontinuous and episodic abundance of woolly mammoths in the Iberian Peninsula during the Late Pleistocene.

The discovery of Mammuthus primigenius remains in south-eastern Spain, at the peat-bog of Padul (Granada) was surprising because of its geographic position. Aguirre et al. (1973) originally reported two woolly mammoth molars from the locality. Regular excavations were carried out in 1982 and 1983 by A. Mazo (Museo Nacional de Ciencias Naturales, Madrid) in a search for further vertebrate remains. The majority of the fossils recovered during these campaigns were later lost, however, some of the remains are now stored in the Geology Department of Granada University and in the Parque de Las Ciencias of Granada (see Section 3). The results of the 1982-1983 field work were 
not published. García and Arsuaga (2003a) reported the existence of mammoth remains at the Padul site in their paper on the distribution of Late Pleistocene cold-adapted mammal faunas of the Iberian Peninsula. New fossils from Padul came to light during the last decades, when two peat-bog quarries were exploited for agricultural use. The new material comprises remains of steppe bison (Bison priscus), red deer (Cervus elaphus) and medium sized horse (Equus sp.) in addition to woolly mammoth. Although red deer may be not considered a typical species of the "mammoth fauna", co-occurrence of Mammuthus primigenius and Cervus elaphus has also been recorded in seven other Iberian sites (Álvarez Lao, 2007).

Given the southern latitude of the Padul location (Fig. 1a), its mammoth fossil assemblage provides information about the southernmost habitats of Late Pleistocene Mammuthus primigenius in Western Europe. The morphometry of the Padul mammoth remains was examined to characterize the individuals represented and confirm whether their anatomy differs from that of contemporaneous mammoths of other regions. The palaeobiogeographic position of the Padul finds is then placed in a global context to redraw the geographic limits and chronology of this animals' southern spread during the Late Pleistocene.

\section{The site of Padul - Geographic position and geological setting}

The Padul Basin is situated in the southernmost region of the Granada Basin, $18 \mathrm{~km}$ south of the city of Granada (SE Spain) at $37^{\circ} 01^{\prime}$ $01^{\prime \prime} \mathrm{N}, 03^{\circ} 36^{\prime} 07^{\prime \prime} \mathrm{W}$, at 700-800 m above sea level (Fig. 1a). The Granada Basin itself is a NW-SE orientated Plio-/Pleistocene intramontane basin of the Betic Cordillera, bounded by two fault systems: the Sierra Nevada range in the north and the Sierra de Albuñuelas in the south (Fig. 1b). In the Padul Basin, which was subsiding during the Quaternary, two alluvial fan systems of erosional debris were deposited. These gravel and sand fans originated from the Sierra Nevada. Distally they evolve into lacustrine peat deposits that emerge in the NW area of the basin. The north-western part of the Padul Basin subsided the most during the Quaternary and therefore acted as the depocentre of a former lake, which initiated the peat formation. The resulting peat-bog covered an area of about $4 \mathrm{~km}^{2}$ (Viseras et al., 2001).

The sediment filling of the Padul Basin reaches a thickness of at least $107 \mathrm{~m}$. The lower half of the sequence consists mainly of gravels, sands and lutites of an alluvial fan system. The upper part is formed by peat, with some thin layers of sands, silts and lutites of lacustrine or palustrine origin (Fig. 1c) (Nestares and Torres, 1998; Ortiz et al., 2004). The
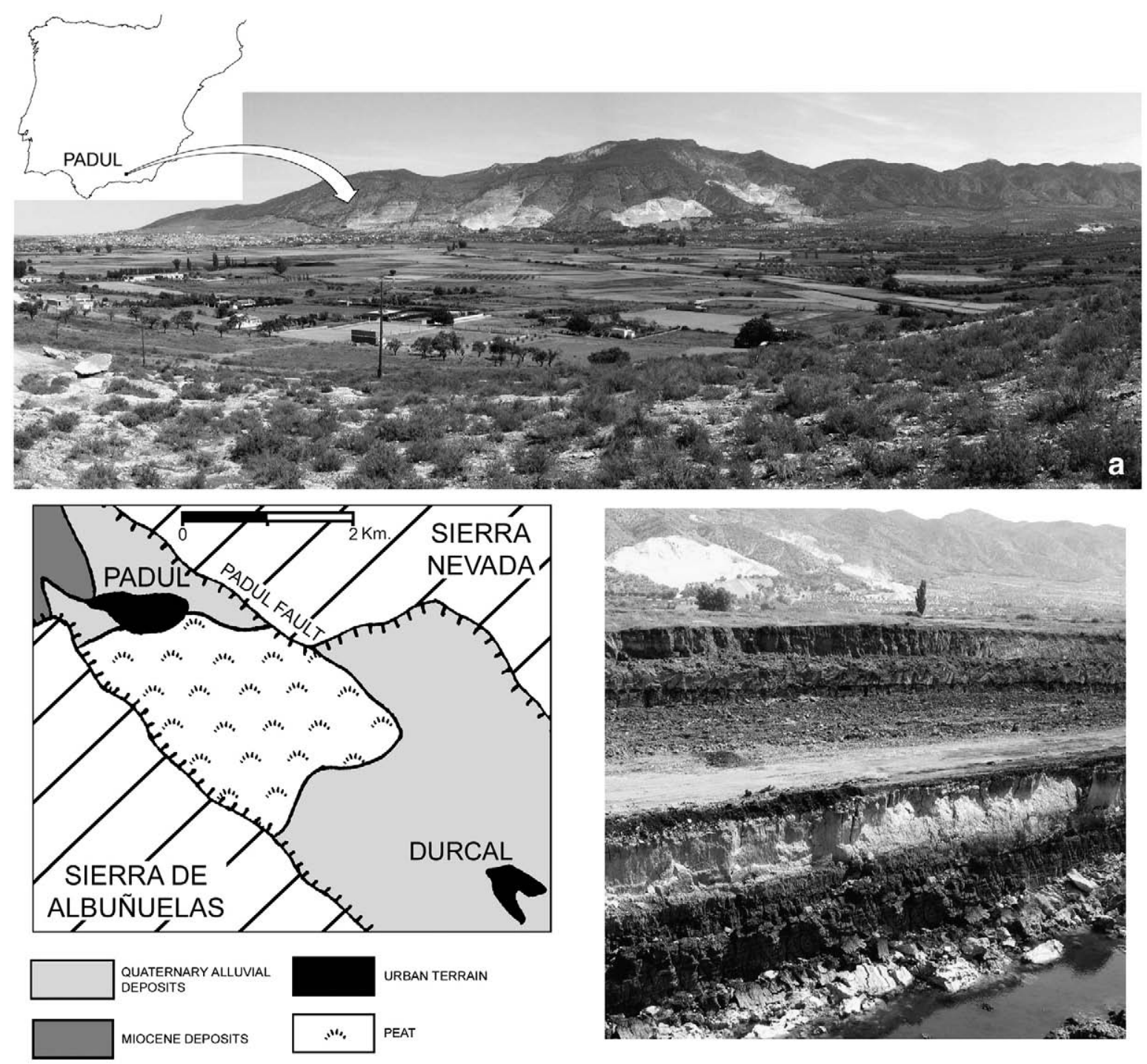

TRIASSIC BASEMENT

Fig. 1. Padul Basin location and landscape (a). Geological structure of the Padul Basin (b). Section of the peat levels where the woolly mammoth remains were found (c). 
geological age of the Padul Basin filling ranges from late Early Pleistocene (ca. $1 \mathrm{Ma}$ BP) to middle Holocene (ca. $4.5{ }^{14} \mathrm{C}$ ka BP) (5.1 cal ka BP). The Padul woolly mammoth remains discussed below originate from the peat and silts of the uppermost ten metres of the peat-bog sequence (E. Martín, Universidad de Granada, personal communication 2004).

\section{The Padul mammoth finds}

\subsection{Material and minimum number of individuals}

The present study is based on the Padul fossils stored at Granada University, in the Parque de Las Ciencias of Granada and on some
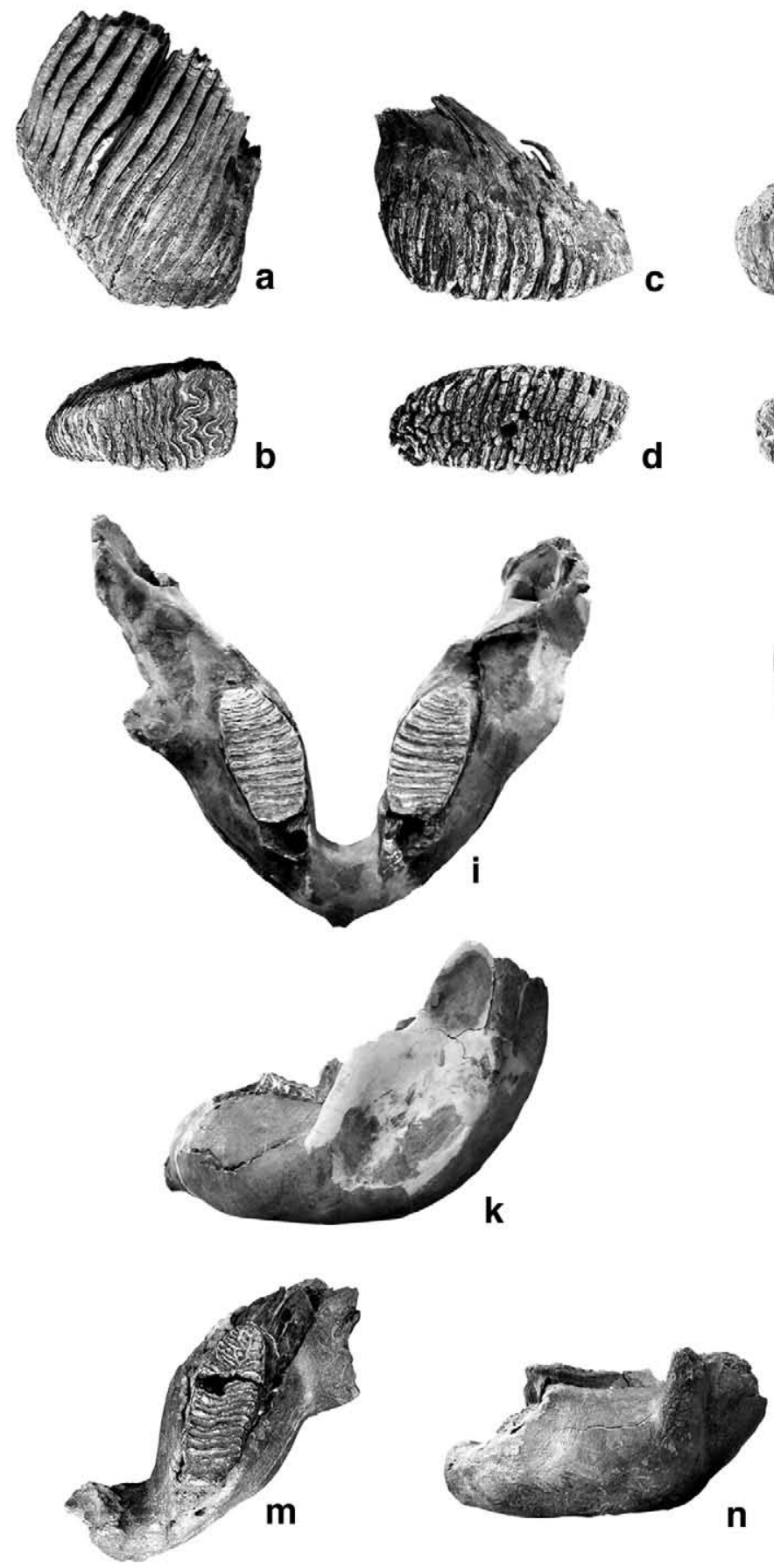
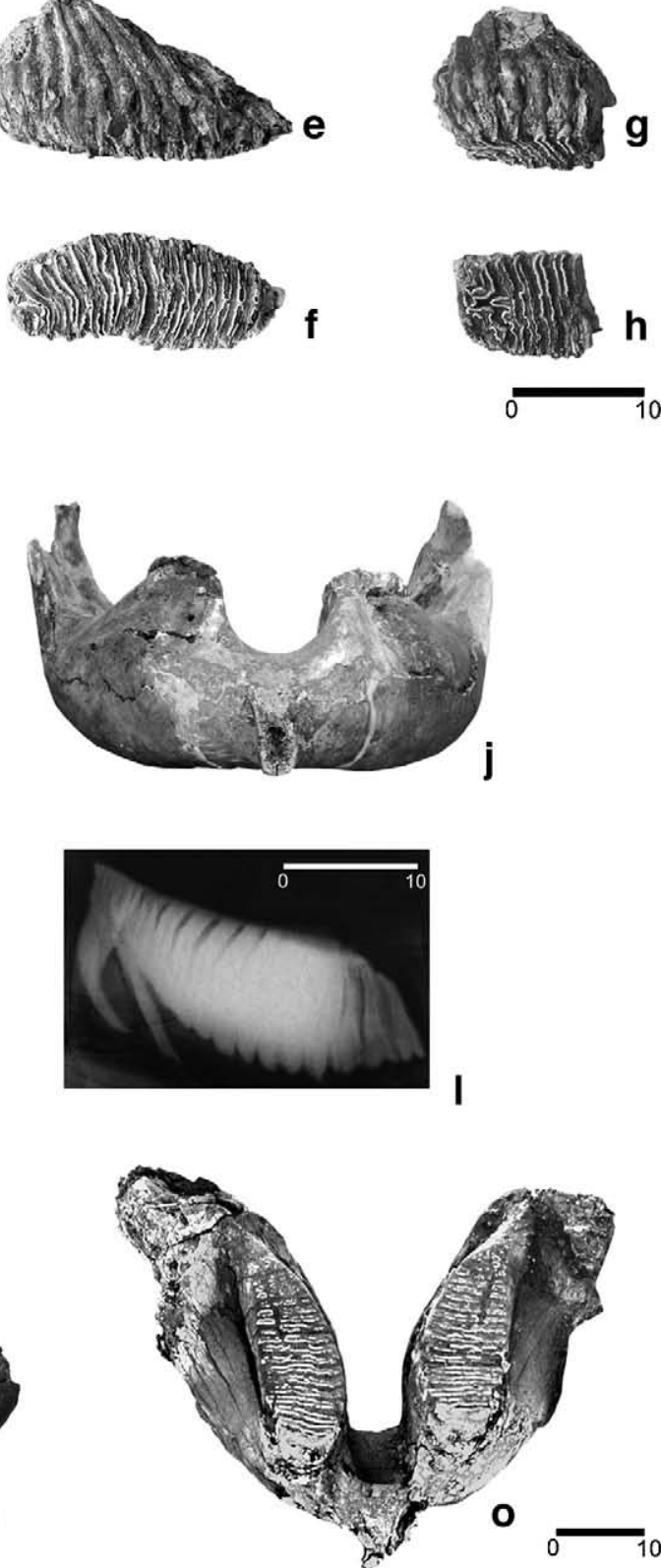

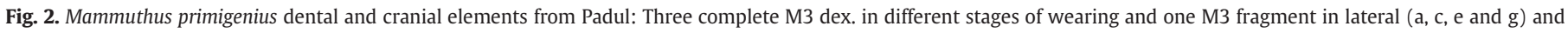

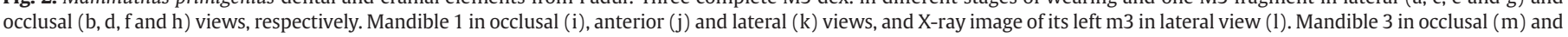
lateral (n) views. Mandible 2: occlusal view (o). Scale bars in $\mathrm{cm}$. 
(2) North-eastern area (1982-1983 excavations): Complete tusk, tusk fragment, almost complete mandible with both $\mathrm{m} 3 \mathrm{~s}$ (mandible 1), incomplete femur dex. lacking the distal extremity, magnum sin., metacarpal II sin., metacarpal V sin., three first phalanges, and four sesamoids. Another nearly complete mandible with the $\mathrm{m} 3$ was also recovered, but cannot be currently traced (mandible 2 )

(3) North-eastern pit (material recovered during quarry works most probably during the 1980 s to 1990 s): Hemimandible sin. with $\mathrm{m} 3$ (mandible 3)

(4) South-western pit: Two M3s dex., distal epiphysis of fibula dex., incomplete femur dex. lacking the proximal epiphysis, patella, unciform dex., metacarpal V dex., cuboideum sin., ectocuneiform sin., two first phalanges, sesamoid.

For transregional comparison of the Padul mammoth remains we used material from the North Sea, recovered between the British Isles and the European mainland and stored in the National Natural History Museum (Naturalis) Leiden, in the Natural History Museum at Rotterdam (both in The Netherlands) and in the collection of one of the authors (D. M). Most of the North Sea material was dredged from the "Brown Ridge". Radiocarbon dates place the mammoth fauna occurrence in the low plains of the southern part of the present day North Sea between $44.1 \mathrm{ka}$ and $28{ }^{14} \mathrm{C} \mathrm{ka}(47.5-32.4 \mathrm{cal} \mathrm{ka} \mathrm{BP})$. Most of them range between 39 and $33{ }^{14} \mathrm{C}$ ka BP (43.2-37.4 cal ka BP) (Glimmerveen et al., 2004). Further, some material in the Museo Nacional de Ciencias Naturales of Madrid (Spain) and from Siberia (data of D. M.) was considered.

The studied Padul woolly mammoth remains belong to at least four individuals. Three are represented by two mandibles and one hemimandible with dentition (mandibles 1-3: Fig. 2i-o, Table 1). An additional isolated M3 dex. cannot be attributed to any of these three mandibles (Fig. 2a, b) because it displays only the first eight plates in use, and indicates an age of death of this fourth individual different from that of the previous ones.

\subsection{Description and individual characteristics}

The complete tusk (Fig. 3a) is $231 \mathrm{~cm}$ long on the external perimeter and shows a very spiralled/twisted curvature, which is characteristic for old male individuals. The basal diameter of this slightly deformed tusk measures approximately c. $17.5 \mathrm{~cm}$.

The almost complete mandible 1 bears both of the $\mathrm{m} 3 \mathrm{~s}$, and part of the alveoli of the $\mathrm{m} 2$ in front of each molar. The mandible is large, heavily built and robust (Fig. 2i-k, Table 1 ) which is, again, characteristic of males. X-rays taken from the specimen (Fig. 21), show that the first root of the left molar is preserved completely and it is very likely that the molars are entirely complete, bearing the original number of lamellae. This indicates that the alveoli in front of the $\mathrm{m} 3$ correspond to the $\mathrm{m} 2$. We count 17 plates, which is an extremely low number of lamellae for an m3 of Late Pleistocene Mammuthus primigenius. Such a low number of lamellae is also known from the Late Pleistocene mammoth locality of Sevsk, Russia (personal observation of one of the authors: D. M.). Following Laws (1966), the individual age for this individual from Padul is estimated to be $43-45 \pm 2$ African Elephant Years (AEY), based on the stage of wear of the molars. The average enamel thickness is $2.02 \mathrm{~mm}$ for the left $\mathrm{m} 3$, and $1.97 \mathrm{~mm}$ for the right one.

Mandible 2, which was found almost complete, is missing, so our plate counts are based on a photograph (Fig. 20) which was taken during its excavation. Two m3s in wear are observed, with the number of plates higher than 24 . The robust nature of mandible 2 confirms that it belongs to a male individual. The wear stage of the molars in the picture implies that this specimen died at an advanced age. The almost complete hemimandible (mandible 3, Fig. $2 \mathrm{~m}-\mathrm{n}$ ) also belonged to an old individual. Like mandible 2 , its robust nature is also suggestive of a male individual. The measurements of all mandibles shown in Table 1 are compared to a sample of mammoth mandibles which were trawled from the bottom of the North Sea. It is to be noted that the values of the Padul mandibles are close to, but slightly larger, than the average values of the whole comparative sample. The lower third molar of mandible 3 shows advanced wear with the last 13 plates in use. The time of death, following Laws (1966), is approximately 53-55 \pm 2 AEY. The enamel is thick, especially in the last plates, with an average thickness of $2.1 \mathrm{~mm}$.

The measurements of enamel thickness and lamellar frequency of three isolated M3s (in different stages of wear) and one M3 fragment (Fig. 2a-h) from Padul are shown in Fig. 4a in comparison to a sample of woolly mammoth M3s from the North Sea and finds from other localities measured in the National Natural History Museum (Naturalis) of Leiden, in the Natural History Museum of Rotterdam, and in the Museo Nacional de Ciencias Naturales of Madrid. The measurements of enamel thickness and lamellar frequency of the $\mathrm{m} 3 \mathrm{~s}$ from the described Padul mandibles are given in Fig. $4 \mathrm{~b}$, compared to a sample from the North Sea localities and other continental European sites. In both the upper and the lower molars from Padul the enamel thickness is relatively high and the corresponding lamellar frequency is relatively low.

One of the femurs from Padul is incomplete (Fig. 3b) and preserves the proximal epiphysis, most of the shaft, but lacks the distal end. The proximal epiphysis is fused, although not entirely. Lister (1999) proposed a method to estimate the woolly mammoth individual age based on the epiphysis fusion of some extremities. These age phases are correlated with the estimated age based on dental development (in AEY; Laws, 1966). According to Lister (I.c.), the most likely age at death of this individual could be estimated to be at least $45 \pm 3$ AEY An estimation of the length was obtained using the regression line plotted in Fig. 5a., which was constructed using a sample of fifteen complete femora from different localities, mainly from the North Sea. Based on the proximal width value $(31.4 \mathrm{~cm})$, the length obtained for the Padul femur is $106 \mathrm{~cm}$. The rest of the measurements of this specimen compared with the North Sea femur sample are listed in

Table 1

Comparative measurements of Mammuthus primigenius lower jaws. Only mandibles with M3 as only teeth in use are included.

\begin{tabular}{|c|c|c|c|c|c|c|c|c|c|}
\hline \multicolumn{2}{|l|}{ Site } & GL & GWhb & GHab & Hhb & $\mathrm{SH}$ & SL & SW & Acb \\
\hline \multicolumn{2}{|c|}{ Padul mandible 1} & 52.9 & 55.9 & 25.3 & 19.3 & 10.0 & 11.5 & 8.9 & $63^{\circ}$ \\
\hline \multicolumn{2}{|c|}{ Padul mandible 3} & & & & 21 & 10.3 & 11.7 & & \\
\hline \multicolumn{2}{|c|}{ Pámanes $^{\mathrm{a}}$} & & & & 16.5 & 8.3 & 18 & 14 & $68^{\circ}$ \\
\hline \multicolumn{2}{|c|}{ Vaciamadrid $^{\mathrm{a}}$} & & & & 16 & 9.3 & 9.2 & 6.5 & $58^{\circ}$ \\
\hline \multicolumn{2}{|c|}{ Taymir old female $\mathrm{a}^{\mathrm{a}}$} & 45 & 41 & 21.5 & 12.5 & 6.5 & 10.8 & 4.3 & $57^{\circ}$ \\
\hline \multirow[t]{4}{*}{ North Sea ${ }^{a}$} & $n$ & 16 & 20 & 18 & 27 & 28 & 25 & 23 & 24 \\
\hline & $\bar{X}$ & 50.4 & 52.36 & 26.12 & 16.4 & 8.68 & 12.39 & 7.53 & $65.4^{\circ}$ \\
\hline & Min-max & $40.3-61$ & $45-65.5$ & $20-31.3$ & $11.8-22.2$ & $5.9-12.7$ & $8.3-19.2$ & $6.4-9.6$ & $53^{\circ}-76^{\circ}$ \\
\hline & SD & 6.15 & 4.49 & 3.39 & 2.83 & 1.66 & 2.78 & 0.97 & $6.34^{\circ}$ \\
\hline
\end{tabular}

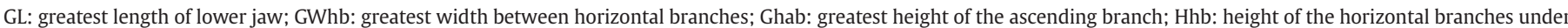
the middle of a functional tooth; SH: symphysis height; SL: symphysis length; SW: symphysis width; Acb: angle of convergence of the branches.

a Own data. 

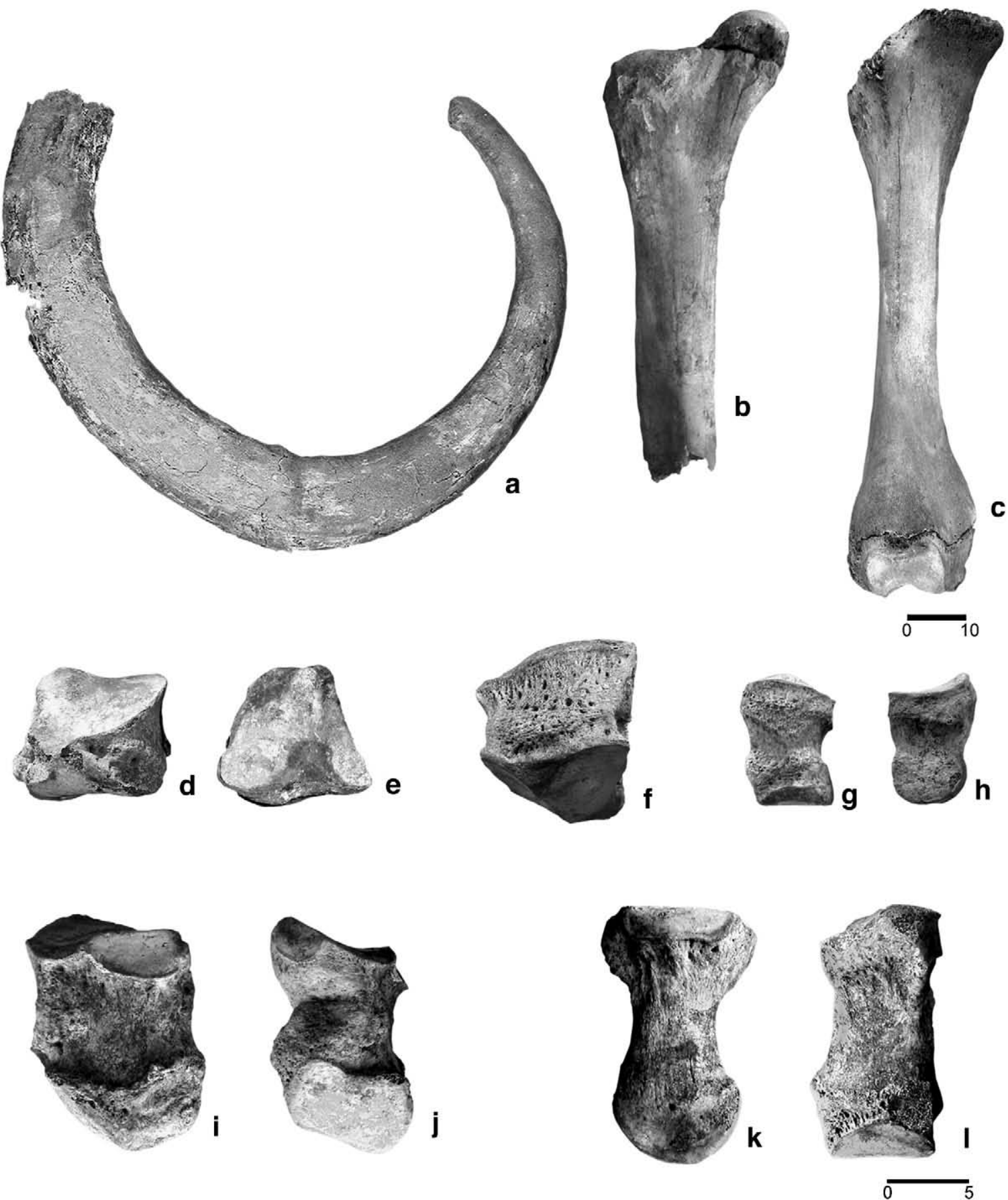

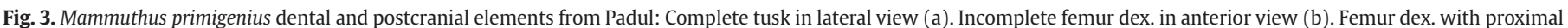

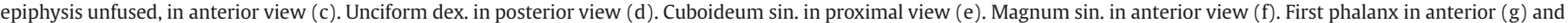
lateral (h) views. Metacarpal V sin. in medial (i) and posterior (j) views. Metacarpal II sin. in lateral (k) and anterior (l) views. Scale bars in cm.

Table 2. The values of the Padul femur fall close to the average values of the comparative sample.

We have also attempted to calculate the shoulder height of this individual based on the estimated length of the femur. Based on nine complete woolly mammoth skeletons published by Garutt (1964), we calculated a shoulder height of $270 \mathrm{~cm}$ for this Padul individual (Fig. 5b). However, a shorter shoulder height is expected for the living animal because the skeletons used in Garutt's work were not mounted in completely correct anatomical position. In many cases the spines of the thoracic vertebrae protrude too far vertically resulting in an exaggerated estimate of shoulder height.
The femur can also provide information about the gender of the individual animal. The assumed maximum length of the described Padul femur (Fig. 3b) is very similar to the femur length of three complete skeletons of woolly mammoth from Arctic Siberia: the Berezovka Mammoth $(109 \mathrm{~cm})$, the Kozlovo Mammoth $(105 \mathrm{~cm})$ and to the neotype of the woolly mammoth, the Taimyr Mammoth $(107 \mathrm{~cm})$. These three skeletons all correspond to male individuals (Averianov, 1996). Based on its size, we ascribe the above mentioned Padul woolly mammoth femur to a male individual. The second Padul femur (Fig. 3c) lacks the proximal epiphysis, which was unfused at the time of death. The distal epiphysis is not entirely fused, which 
a
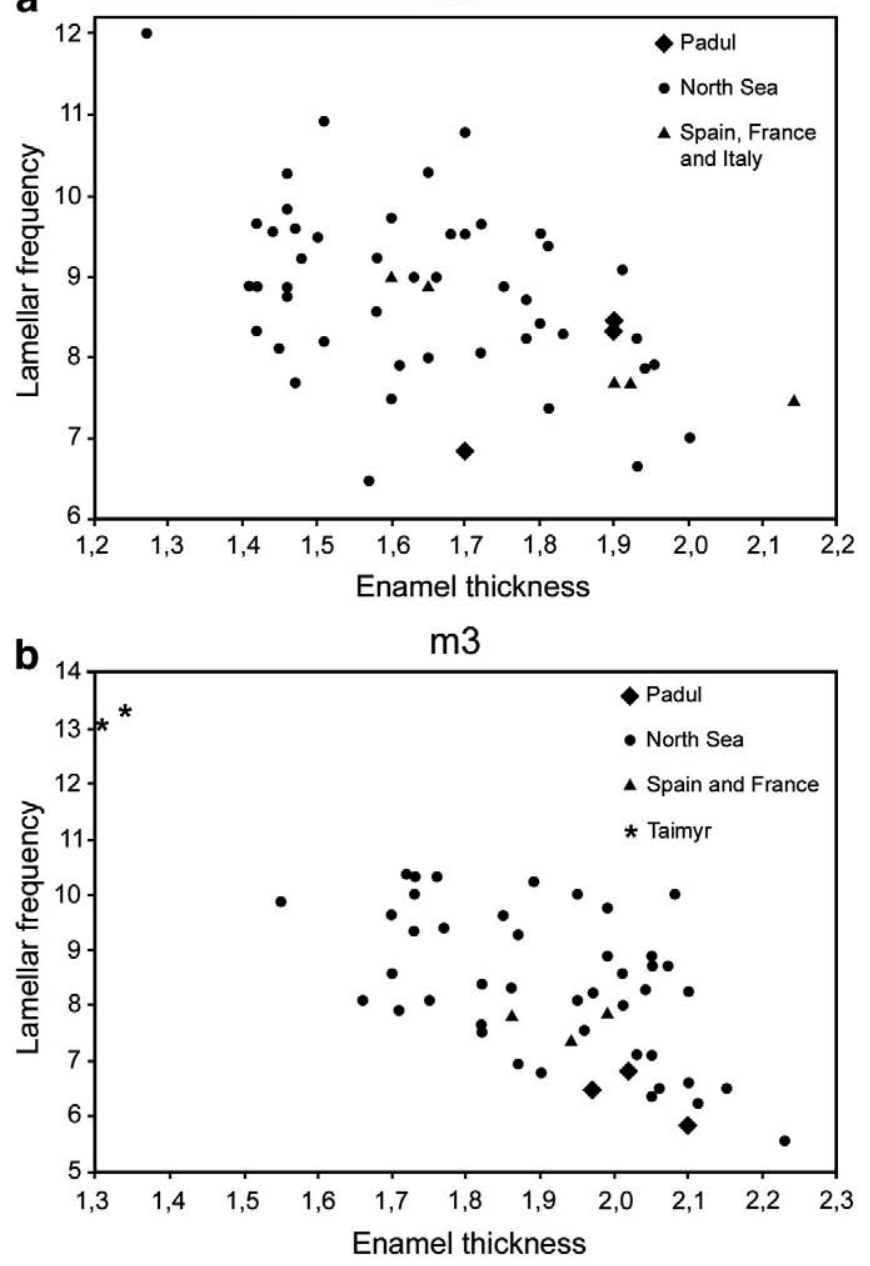

Fig. 4. Comparison of Mammuthus primigenius enamel thickness and lamellar frequency in the upper (a) and lower (b) third molars from various Eurasian localities. Padul specimens are compared with a sample mainly coming from the North Sea, and also from Spain, France, Italy and Taimyr. Measurements of enamel thickness are given in $\mathrm{mm}$.

indicates that this femur belonged to an individual that was not fully grown. Following Lister (1999), the proximal femur epiphysis fuses at the age of $45 \pm 3 \mathrm{AEY}$, and the distal at $33 \pm 3 \mathrm{AEY}$. So, the age at death of this animal based on the femur criteria might range between 33 and 45 AEY.

The preserved carpal, metacarpal and tarsal bones, first phalanges, patella and fibula (Fig. 3d-1), do not show features relevant for further individual details. The measurements of these bones are also similar to the average values obtained from North Sea specimens (Tables 3-5).

The mammoth individuals represented by the Padul sample, do not differ in their morphometry significantly from Late Pleistocene $M$. primigenius from other parts of Europe. Their dental structure shows some conservative features, which are the consequences of their advanced stages of wear. The studied fossil assemblage contains remains of at least four mature or old-age male individuals.

\section{Origin of the Padul mammoth bone accumulation}

A reliable reconstruction of the origin of the Padul Mammoth site is not possible at the moment because the spatial distribution of many of the studied fossils was not documented when they were collected from the peat (see Section 3). Moreover, about a half of the described remains were discovered by quarrymen who probably did not keep small or fragmentary bones, thus creating a sampling bias against juvenile individuals and less robust skeletal elements. This supposition could explain the complete lack of dental or skeletal elements of young and very young individuals, but not the absence of mature females.

The absolute dates of the examined fossils (see below) demonstrate that the four male individuals did not die synchronously, but over a span of several millennia, most likely under similar circumstances. The existence of bogs and open water bodies seems to have attracted all of the individuals in the Padul fossil record. It is likely that the peat-bog acted as a natural trap, as was the case in the English Condover site (Coope and Lister, 1987). However, such an interpretation is not consistent with the fact that Padul mammoth remains were found scattered, without apparent anatomical connection (E. Martín, Universidad de Granada, personal communication 2004). As a rule, the low transportation energy of water currents in paludal environments prevents complete disarticulation of skeletons. In some cases, however, seasonal or periodical floods or water currents can modify this situation. In general, it seems that the disarticulation of the Padul mammoths was not caused by predators as no marks caused by either carnivores or humans have been observed on the bones.

Although the origin of the mammoth taphocoenosis at Padul is not clear, the fossil assemblage may well reflect a kind of selection towards adult male mammoths as a result of their behaviour. Inspired by palaeobiological considerations of the Late Pleistocene Mammoth Site at Hot Springs (South Dakota, USA), we propose a possible

a

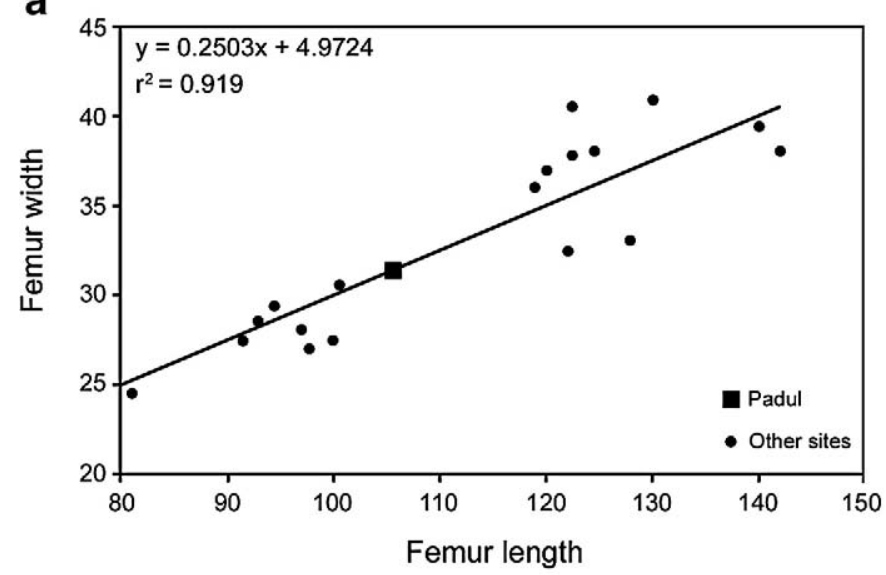

b

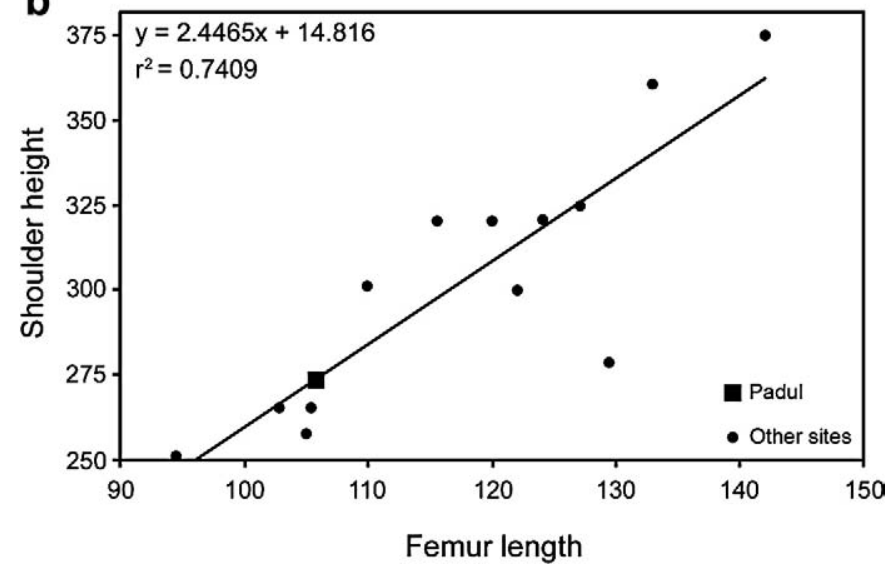

Fig. 5. Estimation of the Padul femur length (incomplete femur) obtained from the proximal width. The regression line correlating width and length has been built from a sample of fifteen complete adult femora from different localities, mainly from the North Sea (a). Estimation of the skeletal shoulder height obtained from the Padul femur length value. The regression line correlating shoulder height and femur length has been built from a sample of nine complete woolly mammoth skeletons from Europe and Siberia published by Garutt (1964) (b). Measurements are given in $\mathrm{cm}$. 
Table 2

Comparative measurements of Mammuthus primigenius femurs. Only complete femurs are included.

\begin{tabular}{|c|c|c|c|c|c|c|c|c|c|}
\hline & & GL & WP & Wcf & Dcf & SWD & SDD & WD & DD \\
\hline Padul 1 & & $106^{\mathrm{a}}$ & 31.4 & 14.7 & 15.2 & 14.2 & 7.3 & & \\
\hline \multirow{3}{*}{$\operatorname{North~Sea~}^{\mathrm{b}}(n=15)$} & $\bar{X}$ & 111.17 & 32.8 & 15.74 & 15.32 & 14.14 & 8.4 & 22.1 & 23.9 \\
\hline & Min-max & $81-140$ & $24.5-40.8$ & $11-19$ & $12-18.3$ & $9.5-17.6$ & $6-10.9$ & $16.5-27.5$ & $16-30$ \\
\hline & SD & 17.49 & 5.52 & 2.31 & 2.07 & 2.65 & 1.55 & 3.93 & 4.49 \\
\hline
\end{tabular}

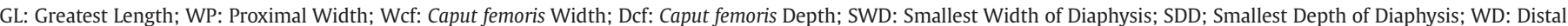
Width; DD: Distal Depth.

a Estimated length.

b Own data.

Table 3

Comparative measurements of Mammuthus primigenius magnums, unciforms, II metacarpals and V metacarpals.

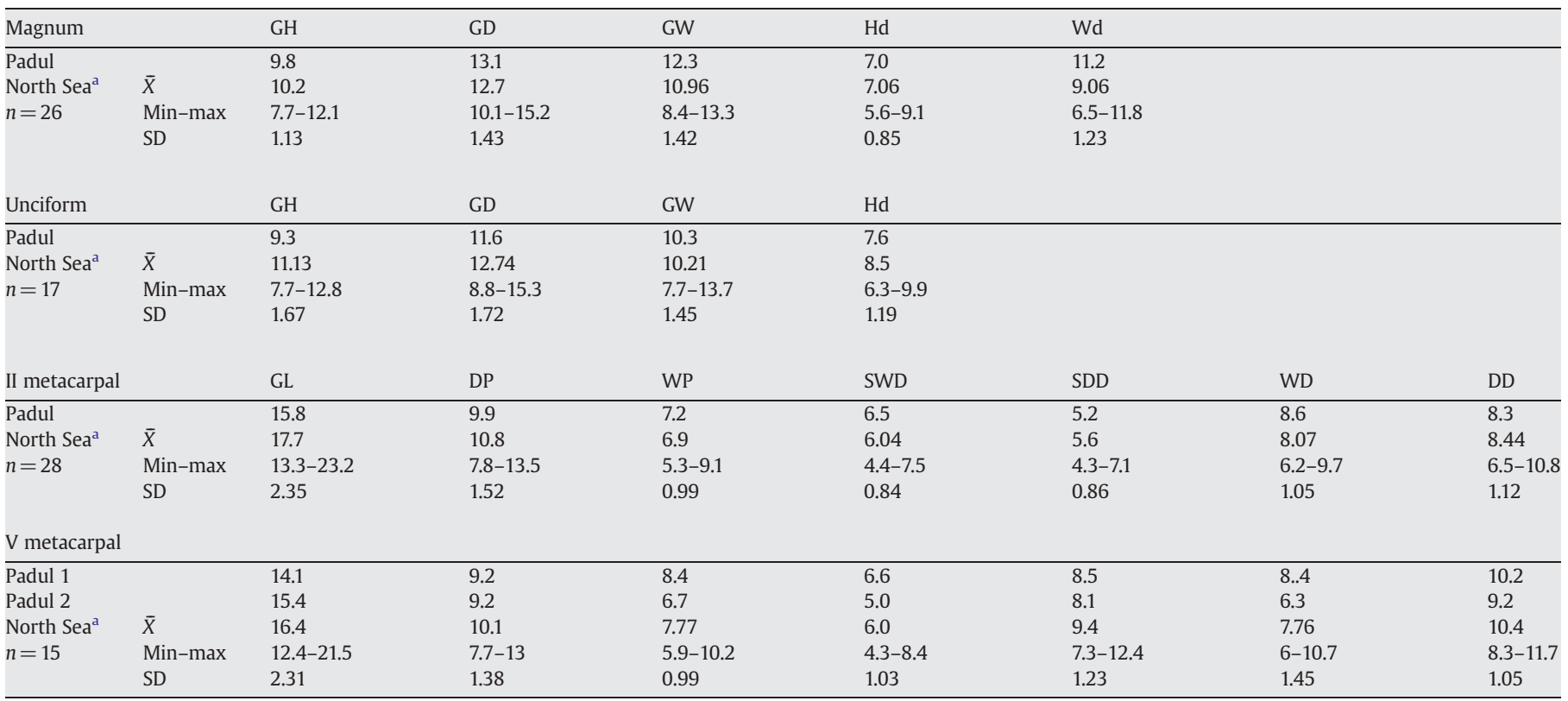

GH: greatest height; GD: greatest depth; GW: greatest width; Hd: dorsal height; Wd: dorsal width; GL: greatest length; DP: proximal depth; WP: proximal width; SWD: smallest width of diaphysis; SDD: smallest depth of diaphysis; WD: distal width; DD: distal depth.

a Own data.

Table 4

Comparative measurements of Mammuthus primigenius ectocuneiforms, cuboideums and phalanges I.

\begin{tabular}{|c|c|c|c|c|c|c|c|c|}
\hline & & & & GH & & GW & & GD \\
\hline Ectocuneifor & & & & & & & & \\
\hline Padul & & & & 4.6 & & 6.7 & & 10.1 \\
\hline North Sea ${ }^{\mathrm{a}}$ & $=8$ & $\bar{X}$ & & 4.3 & & 6.6 & & 10.8 \\
\hline & & Min & & $3.3-6$ & & $5.0-9.1$ & & $8.9-12.4$ \\
\hline & & SD & & 1.15 & & 1.25 & & 1.3 \\
\hline Cuboideum & & & & & & & & \\
\hline Padul & & & & 5.5 & & 10.4 & & 9.7 \\
\hline North Sea ${ }^{a}$ & $=6$ & $\bar{X}$ & & 4.9 & & 11.6 & & 11 \\
\hline & & Min- & & $4.1-5$ & & $10-13.2$ & & $9.3-11.6$ \\
\hline & & SD & & 0.48 & & 1.41 & & 0.99 \\
\hline Phalange I & & GL & WP & DP & SWD & SDD & WD & DD \\
\hline Padul 1 & & 9.5 & 6.3 & 5.9 & 4.6 & 4.4 & 5.5 & 4.4 \\
\hline Padul 2 & & 8.3 & 6.5 & 6.2 & 5.4 & 4.2 & 6.2 & 4.5 \\
\hline Padul 3 & & 7.8 & 7.0 & 5.9 & 5.9 & 4.0 & 6.2 & 4.4 \\
\hline Padul 4 & & 6.1 & 5.5 & 4.2 & 4.1 & 3.2 & 5.3 & 3.2 \\
\hline Padul 5 & & 5.2 & 4.7 & 4.7 & 3.9 & 3.2 & 4.3 & 3.5 \\
\hline North Sea ${ }^{a}$ & $\bar{X}$ & 8.38 & 6.7 & 5.9 & 5.5 & 4.2 & 6.3 & 4.11 \\
\hline$n=10$ & Min- & $4.2-$ & $3.7-$ & 3.5- & $3.4-$ & $2.4-$ & $3.3-$ & 2.7- \\
\hline & $\max$ & 10.3 & 7.8 & 7.2 & 6.5 & 4.8 & 7.5 & 4.8 \\
\hline & SD & 1.75 & 2.71 & 0.98 & 0.99 & 0.69 & 1.19 & 0.66 \\
\hline
\end{tabular}

GH: Greatest Height; GW: Greatest Width; GD: Greatest Depth; GL: Greatest Length; WP: Proximal Width; DP: Proximal Depth; SWD: Smallest Width of Diaphysis; SDD; Smallest Depth of Diaphysis; WD: Distal Width; DD: Distal Depth.

a Own data. scenario explaining the Padul bone accumulation. The Hot Springs site is a karst sinkhole filling, deposited between 26 and $25 \mathrm{ka} \mathrm{BP} \mathrm{(30.9-}$ 29.9 cal ka BP), where remains of some 55 individuals of Mammuthus columbi have been discovered (L. D. Agenbroad, The Mammoth Site of Hot Springs, personal communication 2008). Almost all the individuals found in this natural trap were young adult males. Lister and Agenbroad (1994) also reported behavioural patterns of Loxodonta africana which are consistent with this assemblage. Young male African elephants are often voluntarily or involuntarily expelled from

Table 5

Comparative measurements of Mammuthus primigenius fibulas and patellas.

\begin{tabular}{|c|c|c|c|c|c|c|c|}
\hline \multicolumn{2}{|l|}{ Fibula } & DD & \multicolumn{2}{|c|}{ WD } & Dasc & Wasc & Lde \\
\hline Padul & & 9.8 & 7.2 & & 9.2 & 7.7 & 9.5 \\
\hline \multirow[t]{3}{*}{ North Sea $^{\mathrm{a}}(n=21)$} & $\bar{X}$ & 10.71 & 6.1 & & 8.36 & 7.5 & 9.58 \\
\hline & Min-max & $8.8-13.1$ & 4.8 & 8.4 & $6.4-11.6$ & $5.7-9.4$ & $7.3-13.2$ \\
\hline & SD & 1.43 & 0.9 & & 1.45 & 1.08 & 1.5 \\
\hline \multicolumn{2}{|l|}{ Patella } & \multicolumn{2}{|l|}{ GL } & \multicolumn{2}{|c|}{ GW } & GD & Lcas \\
\hline \multirow{4}{*}{$\begin{array}{l}\text { Padul } \\
\text { North Sea }{ }^{\mathrm{a}}(n=10)\end{array}$} & & \multicolumn{2}{|l|}{12.1} & \multicolumn{2}{|c|}{8.8} & 7.1 & 10.3 \\
\hline & $\bar{X}$ & \multicolumn{2}{|c|}{13.78} & \multicolumn{2}{|c|}{11.13} & 7.34 & 12.4 \\
\hline & Min-max & \multicolumn{2}{|c|}{$11.6-15.4$} & \multicolumn{2}{|c|}{$10.2-13.2$} & $5.7-8.9$ & $10.2-13.6$ \\
\hline & $\mathrm{SD}$ & \multicolumn{2}{|c|}{1.28} & \multicolumn{2}{|c|}{1.04} & 1.07 & 1.16 \\
\hline
\end{tabular}

DD: Distal Depth; WD: Distal Width; Dasc: Depth of articular surface to calcaneum Wasc: Width of articular surface to calcaneum; Lde: Length of distal epiphysis; GL: Greatest Length; GW: Greatest Width; GD: Greatest Depth; Lcas: caudal articular surface Length.

a Own data. 
Table 6

Radiocarbon dates from the Padul mammoth layers.

\begin{tabular}{|c|c|c|c|}
\hline Sample & Laboratory number & ${ }^{14} \mathrm{C}$ age $\mathrm{BP}$ & cal BP years and $68 \%$ range \\
\hline Mammuthus primigenius Lower jaw & Ua-24791 ${ }^{\mathrm{a}}$ & $25,680 \pm 610$ & $30,606(29,932-31,279)$ \\
\hline Mammuthus primigenius M3 (dentine) & Ua- $24790^{\mathrm{a}}$ & $29,335 \pm 990$ & $33,564(32,711-34,417)$ \\
\hline Mammuthus primigenius Lower jaw & Ua-24792 & $33,855 \pm 1215$ & $38,655(36,895-40,414)$ \\
\hline Bison priscus Tibia & Ua-24789a & $34,800 \pm 1360$ & $39,371(37,741-41,001)$ \\
\hline Mammuthus primigenius Carpal bone & UGRA $542^{\mathrm{b}}$ & $35,790 \pm 960$ & $40,467(38,281-41,653)$ \\
\hline
\end{tabular}

${ }^{\text {a }}$ Uppsala Universitet AMS radiocarbon dating.

b Centro de Instrumentación Científica. Universidad de Granada.

family groups, as they have little success in displacing older breeding bulls. The result of this behavioural pattern is solitary individuals or bachelor groups of young males, which are relatively inexperienced in life's dangers, and as a consequence are more likely to get into fatal situations. Even though the age-group of the Padul mammoths is older, this may still correspond to a behavioral pattern of the animals. Perhaps old and non-breeding males of $M$. primigenius were expelled from their herds and met their death when roaming as single individuals in the swampy habitats of the Padul Basin.

\section{Age and palaeoenvironment of the Padul mammoth site}

\subsection{Chronology of the Padul fossil remains}

Radiocarbon dates obtained for this study (Angstrom Laboratory, Uppsala) or taken from the literature cited have been calibrated using the CalPal program to $1 \sigma$ (68\% range), in order to obtain calendar ages (expressed in cal ka $\mathrm{BP}=$ calendric kiloyears before present) as well as to correlate with the palaeoclimate record represented in the Greenland Ice Core Project (GRIP) and the Greenland Ice Sheet Project Two (GISP2) ice cores.

Five radiocarbon dates determined from bone and dentine samples originating from the Padul mammoth layers (Fig. 1c) indicate the presence of Mammuthus primigenius in southern Spain between 35.8 and 25.7 ka BP (40.4-30.6 cal ka BP) (Table 6, Fig. 6). This time span, corresponds with marine isotope stage (MIS) 3, which begins with the extremely cold Heinrich 4 event (H4), an episode of massive iceberg release into the North Atlantic (Rahmsdorf, 2002). MIS 3 subsequently continues with a period characterized by strong and brief climatic oscillations and ends close to another cold and dry period, the $\mathrm{H} 3$ event. These climatic oscillations, recorded in the GRIP and GISP2 ice cores, appear to be of global significance (Dansgaard et al., 1993; Grootes and Stuiver, 1997).

\subsection{Palaeoenvironment}

The palaeoenvironmental context of the Iberian Late Pleistocene has been studied in diverse marine sequences from the Atlantic and Mediterranean margins. At the Atlantic Iberian margin, two deep ocean cores, MD95-2039 and SU-8118 (Turon et al., 2003; Roucoux et al., 2005), provide diverse palaeoclimatic information:

(1) The ice rafted debris (IRD) record shows two main concentrations during the $\mathrm{H} 4$ and $\mathrm{H} 3$ events.

(2) The $\delta^{18} \mathrm{O}$ analyses from planktonic foraminifera, which reflect the sea surface temperature (SST), show the alternating pattern of glacial advance and retreat typical of MIS 3, implying quick climatic changes. This agrees with the Dansgaard-Oeschger cycles (DO) of the Greenland record (Dansgaard et al., 1993).

(3) Pollen analyses from the Atlantic margin indicate a sequence of non-arboreal (steppe) periods alternating with periods of tree cover (Turon et al., 2003; Roucoux et al., 2005). The most representative steppic taxa are Artemisia and Chenopodiaceae, indicators of arid conditions linked with cold climate. The arboreal pollen curve (mainly constituted by Pinus, deciduous Quercus, Betula and Juniperus) shows a fluctuation similar to that observed in the $\delta^{18} \mathrm{O}$ curve. Colder phases and Heinrich events are coincident with maximum steppe pollen and lower arboreal pollen percentages, together with high $\delta^{18} \mathrm{O}$ records and high IRD proportions, whereas warmer phases are characterized by lower $\delta^{18} \mathrm{O}$ oscillations and higher arboreal pollen percentages (Turon et al., 2003; Roucoux et al., 2005). For the time span Mammuthus primigenius existed in the Padul

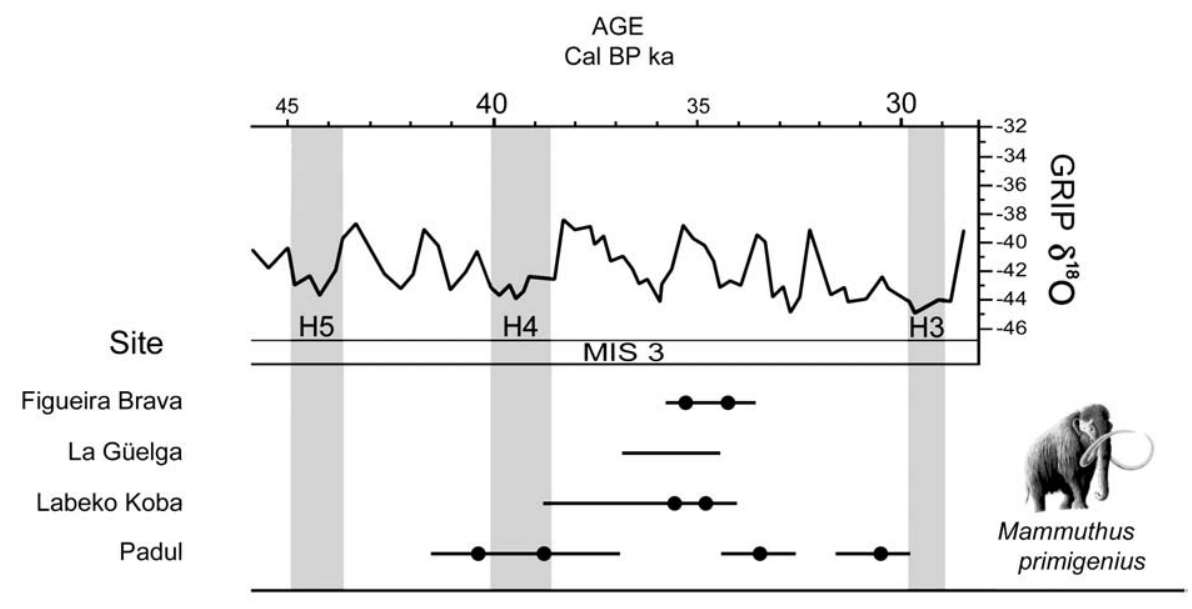

$\longrightarrow$ Absolute dating and the error bar

Nondated finding but with chronology delimited by absolute dates in the nearest upper and lower levels.

Fig. 6. Calibrated radiocarbon dates from Padul and other Iberian woolly mammoth sites from the same chronological range (Roucoux et al., 2005; Álvarez Lao, 2007). 
Basin, the pollen spectrum of the two Atlantic cores shows two main periods with low percentage of arboreal taxa and high proportion of steppic pollen, paralleled by high amounts of dinoflagellate cysts and foraminifera of polar and subpolar affinity indicating decreases in SST. These signals reflect the ecological changes of the $\mathrm{H} 4$ and $\mathrm{H} 3$ intervals.

The drill core MD95-2043, obtained from the Alboran Sea, being the westernmost portion of the Mediterranean Sea between Spain and Morocco, provides further Late Pleistocene data on pollen sequences, SST and $\delta^{18} \mathrm{O}$ records (Moreno et al., 2005). The Alboran Sea is located where northward directed winds carry Saharan dust into the European continent. The resulting influx recorded from core MD952043, supports periods of aridity in northern Africa and in southern parts of the Iberian Peninsula. Increased dust influx into the Alboran Sea is paralleled by low SST and the spread of steppe vegetation on the Iberian Peninsula (Moreno et al., 2005). According to these data, the most pronounced cold periods around the Alboran Sea (about $100 \mathrm{~km}$ southeast of the Padul Basin) happened around $39{ }^{14} \mathrm{C}$ ka (H4), $33{ }^{14} \mathrm{C}$ ka and $30{ }^{14} \mathrm{C}$ ka BP (H3) (43.2 cal ka, 37.5 cal ka and 34.3 cal ka BP, respectively). The climatic oscillations of the past $50 \mathrm{ka}$ recorded from the Alboran Sea, correspond well to the temperature fluctuations of the Greenland cores (Moreno et al., 2005). Thus the climatic signals of the Alboran Sea are also principally related to the palaeoenvironmental evolution of southern Spain including the mammoth bearing peat-bog sequence of Padul.

Palaeoenvironmental data from continental sediments have also been analyzed. In the Padul Late Pleistocene pollen record itself (Florschütz et al., 1971; Pons and Reille, 1988), a clear alternation of arboreal and non-arboreal (steppic) vegetational phases is documented. Non-arboreal taxa are dominated by Artemisia and Poaceae whereas arboreal pollen mainly comprises Pinus. High proportions of Pinus are related to its significant pollen production and the efficiency of its transport by winds over long distances, so an overrepresentation is assumed for this taxon (Turon et al., 2003; Roucoux et al., 2005). Its apparent high percentage in parts of the Padul sequence must, therefore, be interpreted with caution: a high proportion of Pinus pollen could be produced by a small number of pines present some distance from the peat-bog. When woolly mammoths inhabited Padul, generally a high proportion of Artemisia and Poaceae is recorded, whereas the corresponding arboreal pollen is constituted by Pinus. In the diagram given by Pons and Reille (1988), higher percentages of steppic taxa and lower percentages of arboreal taxa are recorded around 29 and $23{ }^{14} \mathrm{C}$ ka BP (33.5 and 27 cal ka BP, respectively).

Additional palaeoenvironmental information on the Padul peat sequence is provided by Ortiz et al. (2004) from elemental, isotopic and molecular organic proxies. Data from the mammoth bone peat level show a high concentration of organic carbon (TOC), which is interpreted as caused by a paludal low water level regime. The $\mathrm{H} / \mathrm{C}$ and $\mathrm{C} / \mathrm{N}$ values in addition to the recorded $\delta^{13} \mathrm{C}$ ratios and the predominant $n$-alkane chains indicate a high proportion of vascular terrestrial (herbaceous and woody) plants in these layers.

Based on the available information given above, Mammuthus primigenius regularly occurred in the Padul Basin during the time span between 40.4 and $30.6 \mathrm{cal} \mathrm{ka}$ BP. The animals reached southern Spain during periods of particularly dry and cold climatic conditions, to occupy steppe-like landscapes, with floral elements typical of the so called tundra-steppe (Guthrie, 1990a,b; West, 2000). Occasional, open pine forests cannot be excluded from the Padul landscape, and would not be unusual habitats for woolly mammoths (Ukraintseva, 1993).

\section{Southern limits of Holarctic Mammuthus primigenius range during the Late Pleistocene}

In addition to the Padul discoveries, another three contemporaneous Iberian Mammuthus primigenius finds (Figs. 6 and 7) have been recorded from Labeko Koba (Guipúzcoa, Spain; 38.9-34.9 cal ka BP; Altuna and Mariezkurrena, 2000), La Güelga (Asturias, Spain; 36.834.4 cal ka BP; M. Menéndez, Madrid, personal communication 2006) and, with some doubts, Figueira Brava (Estremadura, Portugal; 34.2 and $35.1 \mathrm{cal} \mathrm{ka} \mathrm{BP}$; Antunes and Cardoso, 1992), underlining the regularity of woolly mammoth occurrence in the westernmost part of Eurasia. The area immediately northwest of the Pyrenees including a slender belt of dry land south of the submarine (oceanic) North

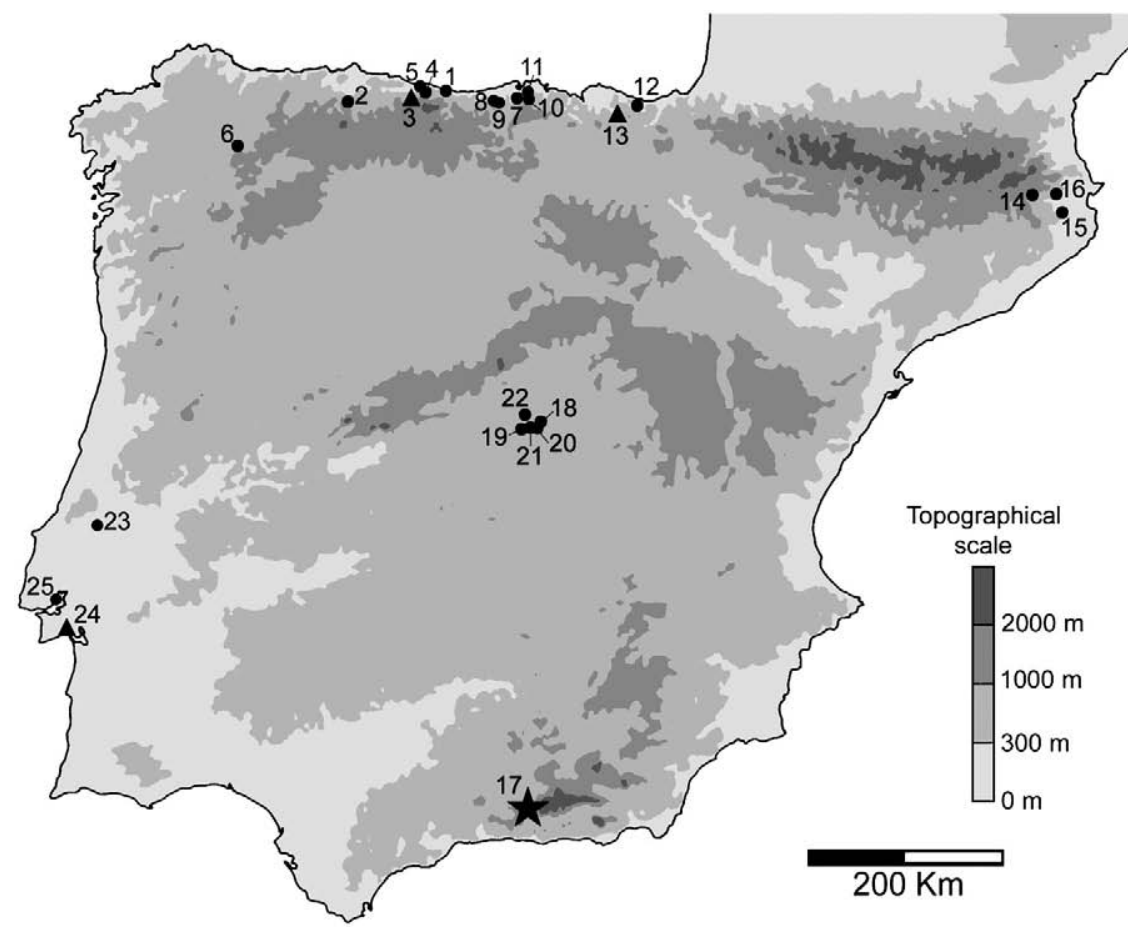

1. Cueto de La Mina

2. Las Caldas

3. La Güelga

4. La Lloseta

5. El Cierro

6. Buján

7. Morín

8. Mina Dolores

9. Mina Ángel

10. Mina inadvertida

11. Minas de Heras

12. Urtiagako Leizea

13. Labeko Koba

14. Clot de Llop

15. Cau de Les Goyes

16. L'Arbreda

17. Padul

18. Arenero Casa Eulogio

19. Aldehuela

20. Arriaga

21. Edar Culebro

22. Butarque

23. Algar de João Ramos

24. Figueira Brava

25. Cruz Quebrada

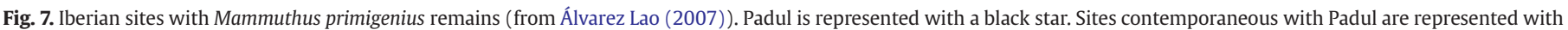
black triangles. 
Spanish Marginal Trough is likely to have been the main migration route of Late Pleistocene M. primigenius from the East into the Iberian Peninsula. Due to the bathymetric situation of the Bay of Biscay (Sibuet et al., 2004), and in stark contrast to the southern bight of the North Sea between the Netherlands and the British Islands, only a minor (coastal) part of the extant Cantabrian Sea fell dry during periods of extended Late Pleistocene glaciations. Although remains of M. primigenius have been reported regularly from Late Pleistocene sites on the northern (French) flank of the Pyrenees (Clot and Duranthon, 1990, site map p. 16), the mountain chain as a whole acted as a barrier to further southward migration of the animals (Fig. 8). The model of a migration route of mammoths into the Iberian Peninsula via the area of extant Basque Country is supported by the relatively large number of fossil localities with woolly mammoth remains in the northern territories of Spain (areas of Guipuzcoa, Cantabria, Asturias, Lugo; Fig. 7). Furthermore, the distribution maps of other Late Pleistocene cold-adapted large mammals (e.g., Gulo gulo, Lynx lynx, Rangifer tarandus) show migrations into northern Spanish regions (Kahlke, 1999; site map in García and Arsuaga, 2003b). The spatial distribution of corresponding records in Iberian Palaeolithic cave art also corresponds to this pattern (site map in García and Arsuaga (2003b)). Moreover, another migration path might have temporarily existed immediately east of the Pyrenees, as nine sites from the counties of Gerona and Barcelona with remains of woolly mammoth, reindeer, musk ox, and woolly rhino (Álvarez Lao, 2007) indicate. The cause of this migration path was also due to a coastal part of the extant Mediterranean Sea becoming dry during the extended coldest periods of Late Pleistocene.

Among the Iberian Late Pleistocene records of Mammuthus primigenius (Fig. 7), the site of Padul has produced the largest amount of identified specimens as well as individuals (see Section 3). With its geographic position near Granada at $37^{\circ} 01^{\prime} \mathrm{N}$, it represents the southernmost European mammoth find recorded so far. The Andalusian Sierra Nevada range likely prevented a further advance of the animals to the Mediterranean coast.

On the Apennine Peninsula, M. primigenius periodically reached the southern part of Central Italy as a relatively rare faunal element (e.g. Sala et al., 1992). The southernmost occurrences were recorded from S. Anna near Veroli (Latium, $41^{\circ} 41^{\prime} \mathrm{N}$; Biddittu and Celletti, 2001) and Cardamone (Apulia, $40^{\circ} 21^{\prime} \mathrm{N}$; Rustioni et al., 2003). Last Glacial migration routes from Eastern Europe into the Apennine Peninsula were opened due to the lowering of the sea level and the resulting emergence of northern parts of the Adriatic Sea (Gallini and Sala, 2001; bathymetric map: Rustioni et al., 2003).

Woolly mammoth probably spread into Greece via Bulgaria (e.g. Poppow, 1913; Nikolov, 1969) and the territories of the former Yugoslavia (Malez, 1986). The record of a (rather primitive) M. primigenius from the Megalopolis basin on the Peloponnesus (Melentis, 1961: $235 \mathrm{ff}$.), found at a latitude $\left(37^{\circ} 24^{\prime} \mathrm{N}\right)$ similar to the Padul remains, appears to have originated from another (probably Ukrainian) site (Lyras, 2007). Koufos (1981) described a Late Pleistocene tusk fragment from the Drama basin in Macedonia $\left(41^{\circ} 09^{\prime} \mathrm{N}\right)$, which may belong to M. primigenius.

During the Last Glacial mammoths spread from the Russian Plain including the Ukraine to the northern shore of the Black Sea and into the lowlands of the Crimea as far as the foothills and low mountains of the Crimea mountain range $\left(44^{\circ} 40^{\prime} \mathrm{N}\right)$ (site maps in Markova et al., 1995; Baryshnikov, 2003). The cave site of Chokurcha 1 near Simferopol in the Crimean lowlands produced more than 3000 fossil mammoth remains (Vereshchagin and Baryshnikov, 1980: 28ff.), however, finds are much less abundant within the more southern mountainous sites.

A few Mammuthus primigenius fossil sites in Georgia indicate that the Caucasus area was not a migratory barrier to the animals (Fig. 8). In the margins of the northern foothills of the Greater Caucasus range, mammoth finds of Late Pleistocene age are not rare (e.g. sites of
Ilskaya 1 and 2; Baryshnikov, 2003). As in the Crimea mountain chain, the animals also penetrated low mountainous areas (Baryshnikov, 2003) - a situation principally comparable to the French part of the Pyrenees (see above). An occasional immigration of $M$. primigenius into Transcaucasia seems to be more likely via the Kuban area (Krasnodar Region), than via the high mountain valleys of the Caucasus crest or the arid areas of Azerbaijan. A review of original material in the Georgian National Museum Tbilisi by one of the authors (R.-D. K.) confirmed the presence of $M$. primigenius in the area near Tbilisi in Georgia (site of Gori at $41^{\circ} 59^{\prime} \mathrm{N}$ ) (Gabunia, 1952; Vereshchagin, 1959: map 76), but that they probably did not enter the more eastern (arid) parts of Georgia and Azerbaijan. While Middle Pleistocene Mammuthus trogontherii is known from Armenia (Avakyan, 1959), no Transcaucasian woolly mammoth remains have been recorded south of Tbilisi so far.

The southern limit of M. primigenius distribution east of the Caspian Sea was marked by the semiarid area of the Betpak Dala (Hunger Steppe) and the Kysylkum desert (Fig. 8). A temporal migration route in south-eastern Kazakhstan, between Lake Balkhash and the Dzungarian Alatau mountain range, allowed the species to enter the area of Almaty and the foothills of the Transili-Alatau $\left(43^{\circ} 10^{\prime} \mathrm{N}\right.$ ) (fossil descriptions: Zhylkibaev, 1975; site list: Kozhamkulova, 1969: 130).

A single fossil record from the site of Da-cang-fang indicates $M$. primigenius occasionally entered the area of the Uigur Region Xinjiang in westernmost China (Tong, 2004). This immigration most likely originated in eastern Kazakhstan and passed through the corridor between the Altai and the Dzungarian Alatau mountain ranges (Fig. 8). Furthermore, $M$. primigenius is recorded from the northern part of the Republic of Mongolia (fossils in the collections of the National Museum of Natural History Ulaan-Baatar), and east Siberia notably the Transbaikalian areas of distribution (Ermolova, 1978: 68ff; Imetkhenov and Kalmykov, 1988: 20ff.; maps of absolute dated sites: Kuz'min et al., 2000; Orlova et al., 2000).

In contrast to western China, a large number of Mammuthus primigenius sites have been reported from the north-eastern part of the country, with especially dense concentrations in the provinces of Heilongjiang and Jilin (overall site maps: Liu and Li, 1989: 518f.; Jin and Kawamura, 1996: 45). As a result of the general problem of subdividing cold stage faunas of late Middle and Late Pleistocene ages in Eastern Asia without absolute dates, it seems problematic to relate all these woolly mammoth records to the period of the Last Glacial. Liu and $\mathrm{Li}$ (1989) reported a distribution of M. primigenius in China restricted to areas north of $38^{\circ} \mathrm{N}$. Tong (2004: 311) mapped the Chinese mammoth distribution, south of the Sea of Bohai, up to $36^{\circ} \mathrm{N}$, without giving site data, and according to Jin et al. (1998) Last Glacial $M$. primigenius had dispersed along the coastal area of China even up to $35^{\circ} \mathrm{N}$. Isolated mammoth finds (two upper molars) were described by Chow and Chang (1974) from Tongwei at $35^{\circ} 12^{\prime} \mathrm{N}$ in the central Chinese province of Gansu as M. primigenius liupanshanensis, however, after Takahashi et al. (2007) these remains should be assigned to a member of the genus Elephas. A confirmed molar of $M$. primigenius was discovered from Ji'nan at Beidasha River (Shandong province) in 1992 at $36^{\circ} 35^{\prime} \mathrm{N}$. At the present time it represents the world's most southerly-recorded $M$. primigenius (Takahashi et al., 2007). The general distribution pattern of Mongolian and Chinese $M$. primigenius occurrences clearly reflects the animals' reaction to extreme aridity. The regions of the Taklamakan and Gobi deserts were strictly avoided (Fig. 8).

On the Korean peninsula, M. primigenius was detected from northeastern North Korea southward up to the province of Ham Kyung (site of Changduk-ni east of the Ham Kyung Mountains, c. $41^{\circ} \mathrm{N}$; Park, 1988 : 79). Furthermore, M. primigenius is mentioned from the Jungwon area in the northernmost part of South Korea at c. $37^{\circ} 50^{\prime} \mathrm{N}$ (Cho and Woo, 2004: 91).

Mammoths reached southern Sakhalin (up to $46^{\circ} \mathrm{N}$ ) (Matsumoto, 1937) and Hokkaido (42 ${ }^{\circ}$ ) (Dubrovo, 1981: 74-76; Kamei, 1981: 169; 


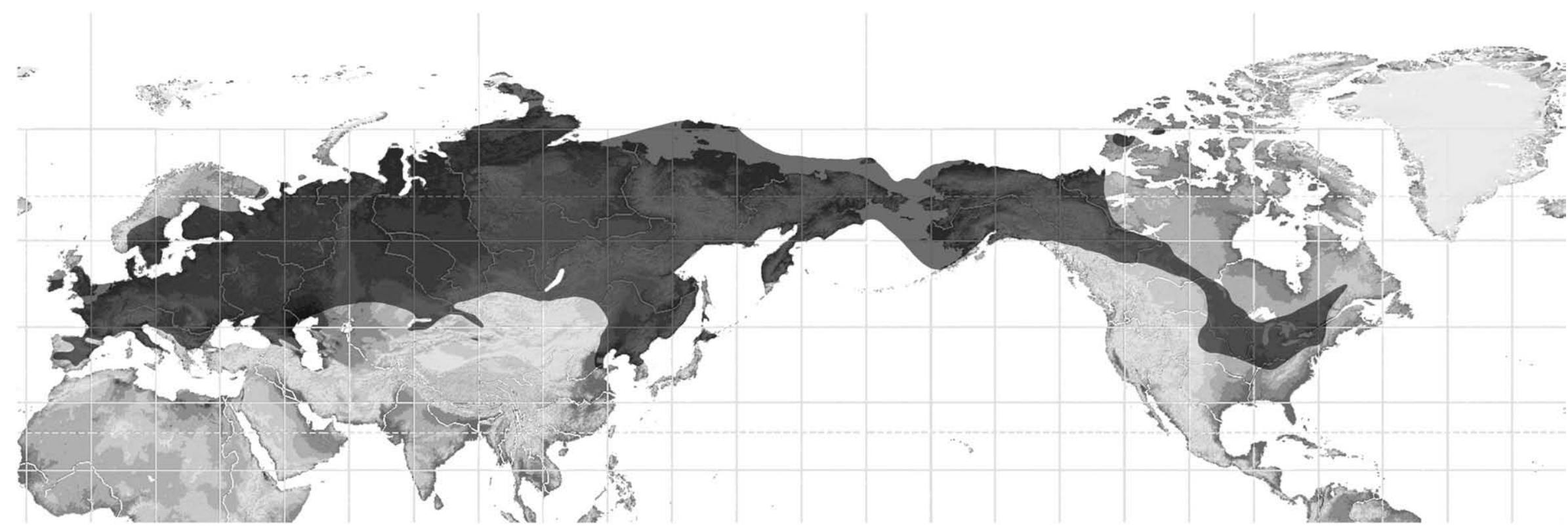

Fig. 8. Sketch of global maximum distribution of the woolly mammoth (Mammuthus primigenius) during the Late Pleistocene (mapping: R.-D. Kahlke, with the benefit of information provided by the references given in the text). 
Takahashi et al., 2006) during periods of low sea level during the Last Glacial (Fig. 8) via the far-eastern Amur region (e.g. Kuz'min et al., 2000). A cast of a mammoth $\mathrm{m} 2$ fragment, reportedly taken from a fossil dredged from the Japanese inland sea in the Prefecture Okayama, was determined by Dubrovo (1981: 76) as belonging to M. primigenius. However, more recently Kawamura (1991: 218, 1994: 10) strictly denied the occurrence of M. primigenius (in addition to Coelodonta antiquitatis) in the Late Pleistocene of the inner HonshuShikoku-Kyushu area. The southernmost Japanese record of a M. primigenius from the last cold stage (the "Sawada specimen") was dredged by a Danish trawler in the Sea of Japan west off the Shimane Prefecture (c. $35^{\circ} 20^{\prime} \mathrm{N}$ ) from c. $200 \mathrm{~m}$ below the current surface, i.e. from a site deeper than the maximal sea level lowering of the Last Glacial Maximum (LGM) (cf. Clark and Mix, 2002). Kamei (1990) proposed that this fossil has drifted from the Huang He area of mainland China, a hypothesis also supported by Takahashi et al. (2006).

The distribution area of Late Pleistocene Mammuthus primigenius is continued in Yakutia and Kamchatka (maps of absolute dated sites in Kuz'min et al., 2000; Orlova et al., 2000) and into the regions of former Beringia and furthermore into northern North America (site bibliographies in Agenbroad and Barton (1991); Harington (2003)). Isolated occurrences are reported from the western part of the Canadian Arctic (MacPhee, 2007). North America's woolly mammoth sites are concentrated in Alaska and across Northern Canada (Fig. 8). The Great Lake region and the Northern Plains of the United States (maps in Agenbroad (1985, 1989); Agenbroad et al. (1994); absolute dated sites in Graham and Lundelius (1994)) were occupied via the ice-free corridor between the Cordilleran and the Laurentide ice sheets, which was probably closed only during the period of the LGM (Dyke et al., 2002). The southernmost limit of the confirmed M. primigenius distribution in North America extended to c. $38-36^{\circ} \mathrm{N}$ (Agenbroad, 1989: Fig. 3.6.; Grady, 1997). After Agenbroad (1989), the woolly mammoth remains reported from south-western areas of the United States, are possibly in error.

From the Southern Plains southwards, the woolly mammoth was replaced by the Columbian mammoth (Mammuthus columbi, inclusive of $M$. jeffersonii), which occupied a grassland belt extending into Central America. The M. columbi find from Villaflores $\left(16^{\circ} 30^{\prime} \mathrm{N}\right)$ in the south-eastern Mexican state of Chiapas (Arroyo-Cabrales et al., 2003) and two molar fragments from the Orillas del Humuya Local Fauna recovered near Comayagua $\left(14^{\circ} 25^{\prime} \mathrm{N}\right.$ ) in Honduras (Webb and Perrigo, 1984) represent the world's southernmost Upper Pleistocene mammoth records known so far.

\section{Chronology of Holarctic Mammuthus primigenius southern distribution during the Late Pleistocene}

Whereas the ages of the Mammuthus primigenius finds from Padul and three more Iberian sites (see Section 6) range between 35.8 and 25.7 ka BP (40.4-30.6 cal ka BP), a second wave of mammoth migration into the Peninsula between 23 and 17 ka BP (27.5-20.3 cal ka BP) is indicated by records from several sites in northern Spain (compilation in Álvarez Lao (2007: 318ff.)). Parallel advances happened at the Apennine Peninsula. In northern Italy (Po Valley) M. primigenius is recorded around 34.5 to $33 \mathrm{ka} \mathrm{BP} \mathrm{(39.7-37.5} \mathrm{cal} \mathrm{ka}$ BP) (Gallini and Sala, 2001). A further expansion of mammoths reached central Italy between 22 and 18 ka BP (26.4-21.7 cal ka BP) (Rustioni et al., 2003; Palombo et al., 2005).

In contrast to south-west Europe, all dated mammoth sites of the Crimea are older than 35 ka BP (40.1 cal ka BP) (Markova et al., 1995: 25, Fig. 1, 2001: 299). Younger, more northward-situated sites are known from the Russian Plain (map in Markova et al., 2001; Stuart et al., 2002). The single mammoth tooth from Gori in Georgia was found in a river terrace of probably terminal-Pleistocene age (Gabunia, 1952: 154). The southernmost M. primigenius remains of Kazakhstan, western China and Mongolia have not been radiocarbon-dated yet. Asia's southernmost mammoth record from eastern China (Beidasha river; see Section 5) was dated to c. 33 ka BP (37.5 cal ka BP) (Takahashi et al., 2007). Three of Japan's eleven mammoth finds known so far, fit into the 21 to $16 \mathrm{ka}$ BP (25.1-19.1 cal ka BP) interval, the other ones are of uncertain age or older than $37 \mathrm{ka}$ ( $41.8 \mathrm{cal} \mathrm{ka}$ BP) (Takahashi et al., 2006). Most of them originate from Hokkaido. On Kamchatka, woolly mammoth is recorded from the 36 to 33 ka BP (41.3-37.5 cal ka BP) and 24 to $20 \mathrm{ka} \mathrm{BP} \mathrm{(28.8-23.9} \mathrm{cal} \mathrm{ka} \mathrm{BP)} \mathrm{intervals}$ as well as between 13 and $12 \mathrm{ka} \mathrm{BP} \mathrm{(15.8-13.9} \mathrm{cal} \mathrm{ka} \mathrm{BP)} \mathrm{(Orlova} \mathrm{et} \mathrm{al.,}$ 2000: Tab.).

For North America's southernmost woolly mammoth finds absolute dates are largely lacking (Graham and Lundelius, 1994). However, a number of dates from the Mammoth Site of Hot Springs (South Dakota; see Section 4), deposited between 26 and 25 ka BP (detailed data in Agenbroad, 1994, 26-27; 30.9-29.9 cal ka BP), shed some light on the migratory history of Late Pleistocene M. primigenius into moderate latitudes of North America. While fossils of more than 50 mammoth individuals filling the karst sinkhole at the Hot Springs site belong to Mammuthus columbi, the remains of three individuals of $M$. primigenius appeared in the upper stratigraphic units of the site (Agenbroad, 1994), indicating dispersal of the species to at least $43^{\circ} \mathrm{N}$. This expansion led to a co-occurrence or even to a temporal replacement of $M$. columbi by M. primigenius in the North American Midwest around 30 cal ka BP.

\section{Conclusions}

The occurrence of Mammuthus primigenius between 40.4 and 30.6 cal ka BP in southern Spain was not an accidental or singular biogeographic event. During this time span the animals repeatedly occupied steppe-like landscapes of the Iberian Peninsula, when sufficient amounts of suitable plants allowed their subsistence. The Padul mammoths did not differ morphometrically from individuals of contemporaneous populations of other parts of Europe, but represent the westernmost part of a continuous, Holarctic extended belt of mammoth distribution (Fig. 8). The southernmost migrations of Iberian woolly mammoths correlate with periods of particularly dry and cold climatic conditions, as they are documented in terrestrial and marine sediment sequences of the region (see Section 5). Moreover, the temporal coincidence of the southernmost occurrences of Late Pleistocene M. primigenius in Europe with cold climatic phases in Greenland (see Section 5) and East Asia (see below) classifies the Padul mammoth finds as evidence of transregional palaeoecological processes.

The southern expansion of Mammuthus primigenius during the Late Pleistocene extended to similar latitudes in Eurasia and North America, paralleling the distribution of suitable steppe- or tundrasteppe ("mammoth steppe") like environments. The southernmost woolly mammoth remains of Europe from Padul have been recorded at c. $37^{\circ} \mathrm{N}$, those in Asia between $37^{\circ}$ and $36^{\circ} \mathrm{N}$, and the North American ones between c. $38^{\circ}$ and $36^{\circ} \mathrm{N}$ (see Section 6). The woolly mammoth's southernmost spreads were limited by the following factors:

(1) The replacement of tundra-steppe by extended grasslands (North American "prairie", which obviously supported the spread of Mammuthus columbi) or landscapes with unsuitable vegetation (Eurasia, North America);

(2) The configuration of marine shore lines (Europe, Asia);

(3) The configuration of more or less E-W directed high mountain chains (Europe, Asia); and

(4) The configuration of semideserts and deserts (Asia).

Evaluation of the limited number of radiocarbon dates available that relate to the southernmost range expansions of woolly mammoth in Eurasia and North America, means that a general picture of 
the Late Pleistocene southern migration of Mammuthus primigenius can only be drawn with caution. The phases of mammoth immigration into the Iberian and Apennine Peninsulas during the later part of MIS 3 and early MIS 2 (see Section 7) can be roughly correlated with the spread of the species in the eastern Palaearctic, namely in eastern China, northern Japan and Kamchatka. Such coherence of Late Pleistocene mammoth dispersals at the western and eastern margin of Eurasia is supported by correlations of North Atlantic and East Asian climatic signals: The Heinrich events recorded from the North Atlantic region, left their signature in the grain-size spectra of Chinese loess sequences (Porter and An, 1995). The timing of temperature changes recorded from the GISP2 ice core between 30 and $11 \mathrm{ka}$ BP (34.3-12.9 cal ka BP) changed in concert with the East Asian monsoon intensity, as detected in oxygen isotope records of stalagmites at Hulu Cave near Nanjing in eastern China (Wang et al., 2001). Moreover, recent studies demonstrate that the Greenland DO cycles correlate well with contemporaneous pollen records in Northeast China (Stebich et al., 2008).

The parallel advances of woolly mammoths detected in western Europe and eastern Asia were controlled by connected climatic processes in marine (northeast Atlantic, northwest Pacific) influenced areas. However, along the eastern coast of the Pacific Ocean, the topography and glaciation of the Rocky Mountain range prevented a similar dispersal of woolly mammoths into western North America as happened in both of the Eurasian continental margins. The southern immigration of Late Pleistocene $M$. primigenius within the innercontinental areas of Eurasia and North America seems to reflect a climatic evolution different from those of the oceanic influenced regions. More absolute dates are needed to understand the temporospatial pattern of the southern distribution of woolly mammoths in the interior of the continents.

\section{Acknowledgements}

Our study was supported by the Universidad de Oviedo project CN04-218, directed by G. Adan (Oviedo), J.L. Arsuaga (Madrid) and M. Arbizu (Oviedo), who granted one of the authors (D. Á.-L.). The manuscript is also a result of the Senckenberg Research Institute's project group "Origin, dispersal and impoverishment of Eurasian cold faunas" (R.-D. K.). For information, discussion, access to the collections under their care and various further supports our thanks are due to $\mathrm{E}$. Martín and T. Freudenthal (both from Granada), F. Lacombat (Le Puyen-Velay and Weimar), D. Lordkipanidze (Tbilisi), M.R. Palombo (Rome), J. W. F. Reumer (Rotterdam), M. Stebich (Weimar), E. Tsoukala (Thessaloniki) and J. de Vos (Leiden). We are also very grateful to R. Feranec (New York) and C. Smith (Leipzig) for their help with the language corrections, A. J. Stuart (London and Durham) and an anonymous reviewer who greatly helped to improve this paper.

\section{References}

Agenbroad, L.D., 1985. The distribution and chronology of Mammoth in the New World. Acta Zoologica Fennica 170, 221-224.

Agenbroad, L.D., 1989. New world mammoth distribution. In: Martin, P.S., Klein, R.G. (Eds.), Quaternary Extinctions. A Prehistoric Revolution. University of Arizona Press, Tucson, pp. 90-108.

Agenbroad, L.D., 1994. Geology, hydrology, and excavation of the site. In: Agenbroad, L.D., Mead, J.I. (Eds.), The Hot Springs Mammoth Site: A Decade of Field and Laboratory Research in Paleontology, Geology, and Paleoecology. Fenske, Rapid City, pp. 15-27.

Agenbroad, L.D., Barton, B.R., 1991. North American Mammoths: An Annotated Bibliography 1940-1990. Mammoth Site of Hot Springs Scientific Papers, vol. 2, pp. 1-118.

Agenbroad, L.D., Lister, A.M., Mol, D., Roth, V.L., 1994. Mammuthus primigenius remains from the Mammoth Site of Hot Springs, South Dakota. In: Agenbroad, L.D., Mead, J.I (Eds.), The Hot Springs Mammoth Site: A Decade of Field and Laboratory Research in Paleontology, Geology, and Paleoecology. Fenske, Rapid City, pp. 269-281.

Aguirre, E., Lhenaff, R., Zazo, C., 1973. Nuevos fósiles de elefantes en Andalucía. Estudios Geológicos 29, 295-306

Altuna, J., Mariezkurrena, K., 2000. Macromamíferos del yacimiento de Labeko Koba (Arrasate, País Vasco). In: Arrizabalaga, A., Altuna, J. (Eds.), Labeko Koba (País
Vasco): Hienas y humanos en los albores del Paleolítico Superior. Munibe (Antropología-Arkeología), vol. 52, pp. 107-181.

Álvarez Lao, D.J., 2007. Revisión paleontológica de los macromamíferos indicadores de clima frío en la Península Ibérica - Ph.D. Thesis, Universidad de Oviedo, Departamento de Geología, Oviedo, Spain, p. 413.

Antunes, M.T., Cardoso, J.L., 1992. Quaternary elephants in Portugal: new data. Ciências da Terra (UNL) 11, 17-37.

Arroyo-Cabrales, J., Polaco, O.J., Johnson, E, Guzmán, A.F, 2003. The distribution of the genus Mammuthus in Mexico. In: Reumer, J.W.F., de Vos, J., Mol, D. (Eds.), Advances in Mammoth Research. Proceedings of the Second International Mammoth Conference. Rotterdam, 16-20 May 1999. Deinsea, vol. 9, pp. 27-39.

Avakyan, L.A., 1959. Chetvertichnye iskopaemye mlekopitayushchie Armenii. Izdatelstvo AN Armyanskoj SSR, Erevan, p. 72 (in Russian).

Averianov, A.O., 1996. Sexual dimorphism in the mammoth skull, teeth and long bones. In: Shoshani, J., Tassy, P. (Eds.), The Proboscidea: Evolution and Palaeoecology of Elephants and Their Relatives. Oxford University Press, pp. 260-267.

Baryshnikov, G., 2003. Mammuthus primigenius from the Crimea and the Caucasus. In: Reumer, J.W.F., de Vos, J., Mol, D. (Eds.), Advances in Mammoth Research. Proceedings of the Second International Mammoth Conference. Rotterdam, 16-20 May 1999. Deinsea, vol. 9, pp. 41-56

Biddittu, I., Celletti, P., 2001. Plio-Pleistocene Proboscidea and Lower Palaeolithic bone industry of southern Latium (Italy). In: Cavarretta, G., Gioia, P., Mussi, M., Palombo, M.R. (Eds.), The World of Elephants. Proceedings of the 1st International Congress, Roma, 16-20 Ottobre 2001. Consiglio Nazionale delle Ricerche, Roma, pp. 91-96.

Cho, T.-S., Woo, J.-Y., 2004. La fauna préhistorique et al subsistence de la région Jungwon en Corée. In: Lee, Y.-J., Cho, T.-S. (Eds.), Paleoenvironment et culture paleolithique de la Region Jungwon, Corée. Institute for Jungwon Culture, Chungbuk National University, Seoul, pp. 89-99.

Chow, M.C., Chang, Y.P., 1974. Proboscidea of China. Science Press, Beijing. p. $74+$ pl. XXXII. (in Chinese)

Clark, P.U., Mix, A.C., 2002. Ice sheets and sea level of the Last Glacial Maximum. Quaternary Science Reviews 21,1-7.

Clot, A., Duranthon, F., 1990. Les mammifères fossiles du Quaternaire dans les Pyrénées. Museum d'Histoire Naturelle de Toulouse, Toulouse, p. 159.

Coope, G.R., Lister, A.M., 1987. Late-glacial mammoth skeletons from Condover, Shropshire, England. Nature 330, 472-474.

Dansgaard, W., Johnsen, S.J., Clausen, H.B., Dahl-Jensen, D., Gundestrup, N.S., Hammer, C.U., Hvidberg, C.S., Steffensen, J.P., Sveinbjörnsdottir, A.E., Jouzel, J., Bond, G., 1993. Evidence for general instability of past climate from a $250 \mathrm{kyr}$ ice-core record. Nature 364, 218-220.

Dubrovo, I.A., 1981. Die fossilen Elefanten Japans. Quartärpaläontologie 4, 49-84.

Dyke, A.S., Andrews, J.T., Clark, P.U., England, J.H., Miller, G.H., Shaw, J., Veillette, J.J., 2002. The Laurentide and Innuitian ice sheets during the Last Glacial Maximum. Quaternary Science Reviews 21, 9-31.

Ermolova, N.M., 1978. Teriofauna doliny Angary v pozdnem anthropogene. Izdatelstvo Nauka, Sibirskoe otdelenie, Novosibirsk, p. 222 (in Russian).

Florschütz, F., Menéndez Amor, J., Wijmstra, T.A., 1971. Palynology of a Thick Quaternary succession in Southern Spain. Palaeogeography, Palaeoclimatology, Palaeoecology 10 (4), 233-264.

Gabunia, L.K., 1952. O zube "Karlikovogo" mamonta iz Gori. Soobshcheniya Akademii Nauk Gruzinskoj SSR 13 (3), 153-154

Gallini, V., Sala, B., 2001. Settepolesini di Bondeno (Ferrara - Eastern Po Valley): the first example of mammoth steppe in Italy. In: Cavarretta, G., Gioia, P., Mussi, M., Palombo, M.R (Eds.), The World of Elephants. Proceedings of the 1st International Congress, Roma, 16-20 Ottobre 2001. Consiglio Nazionale delle Ricerche, Roma, pp. 272-275.

García, N., Arsuaga, J.L., 2003a. Last Glaciation cold-adapted faunas in the Iberian Peninsula. In: Reumer, J.W.F., De Vos, J., Mol, D. (Eds.), Advances in Mammoth Research (Proceedings of the Second International Mammoth Conference, Rotterdam, May 16-20 1999). DEINSEA, vol. 9, pp. 159-169.

García, N., Arsuaga, J.L., 2003b. Late Pleistocene cold-resistant faunal complex: Iberian occurrences. In: Ruiz Zapata, M.B., Dorado Valiño, M., Valdeolmillos Rodriguez, A., Gil Garcia, J., Bardaji Azcárate, T., de Bustamante Gutiérrez, I., Martinez Mendizábal, I. (Eds.), Quaternary climatic changes and environmental crises in the Mediterranean Region. Universidad de Alcalá, Alcalá de Henares, pp. 149-159.

Garutt, W.E., 1964. Das Mammut. A. Ziemsen Verlag, Wittenberg Lutherstadt, pp. 1-140.

Glimmerveen, J., Mol, D., Post, K., Reumer, J.W.F., van der Plitch, H., de Vos, J., van Geel, B., van Reenen, G., Pals, J.P., 2004. The North Sea Project: the first palaeontological, palynological and archaeological results. In: Flemming, N.C. (Ed.), Submarine prehistoric archaeology of the North Sea: Research priorities and collaboration with industry. CBA Research Report. English Heritage/Council for British Archaeology, vol. 141 , pp. 43-52.

Grady, F., 1997. Mammuthus primigenius from Endless Caverns: the First Cave Record of Mammoth from Virginia. Journal of Cave and Karst Studies 59 (3), 173-174.

Graham, R.W., Lundelius Jr., E.L., (Faunmap Working Group), 1994. Faunmap: A Database Documenting Late Quaternary Distributions of Mammal Species in the United States. Illinois State Museum Scientific Papers, vol. 25 (1). viii + 1-287, 25 (2), vii + 289-690

Grootes, P.M., Stuiver, M., 1997. Oxygen 18/16 variability in Greenland snow and ice with $10^{-3}$ - to $10^{5}$-year time resolution. Journal of Geophysical Research 102, $26,455-26,470$

Guthrie, R.D., 1990a. Late Pleistocene faunal revolution - a new perspective on the extinction debate. In: Agenbroad, L.D., Mead, J.I., Nelson, L.W. (Eds.), Megafauna \& Man. Discovery of America's Heartland. Scientific Papers, 1. The Mammoth Site of Hot Springs, South Dakota, pp. 42-53.

Guthrie, R.D., 1990b. Frozen Fauna of the Mammoth Steppe: the Story of Blue Babe. The University of Chicago Press, pp. 1-323. 
Harington, C.R. (Ed.), 2003. Annotated Bibliography of Quaternary Vertebrates of Northern North America with Radiocarbon Dates. Toronto University Press, Toronto, p. 539.

Imetkhenov, A.B., Kalmykov, N.P., 1988. Fauna i flora kajnozoya Buryatii. Buryatskij filial SO AN SSSR, Ulan-Ude, p. 181 (in Russian).

Jin, C.-Z., Kawamura, Y., 1996. Late Pleistocene mammal fauna in Northeast China: mammal fauna including woolly mammoth and woolly rhinoceros in association with Paleolithic tools. Earth Science (Chikyu Kagaku) 50, 315-330.

Jin, C., Xu, Q., Zheng, J., 1998. On the dispersal events of Mammuthus during the late Late Pleistocene. Vertebrata PalAsiatica 36 (1), 47-53 (in Chinese, with English summary).

Kahlke, R.-D., 1999. The History of the Origin, Evolution and Dispersal of the Late Pleistocene Mammuthus-Coelodonta Faunal Complex in Eurasia (Large Mammals). Fenske Companies, Rapid City, p. 219.

Kahlke, R.-D., 2001. Ein Meer voller Knochen? Pleistozäne Wirbeltierreste aus der Scheldemündung und vom Nordseeboden. Natur und Museum 131 (12), 417-432.

Kahlke, R.-D., Mol, D., 2005. Eiszeitliche Großsäugetiere der Sibirischen Arktis. Die Cerpolex/Mammuthus-Expeditionen auf Tajmyr. Senckenberg-Buch, vol. 77. Schweizerbart Verlag, Stuttgart, p. 96.

Kamei, T., 1981. Faunal succession of Pleistocene mammals in the Japanese Islands: an aspect. Quartärpaläontologie 4, 165-174.

Kamei, T., 1990. The Japan Sea and elephants. Quaternary Research 29 (3), 163-172 (in Japanese, with English summary).

Kawamura, Y., 1991. Quaternary Mammalian faunas in the Japanese Islands. Quaternary Research 30 (2), 213-220.

Kawamura, Y., 1994. Late Pleistocene to Holocene mammalian faunal succession in the Japanese Islands, with comments on the Late Quaternary extinctions. Archaeozoologia $6(2), 7-22$.

Koufos, G., 1981. A new Late Pleistocene (Würmian) mammal locality from the basin of Drama (Northern Greece). Scientific Annals of the Faculty of Physics and Mathematics, University of Thessaloniki 21 (129), 129-148.

Kozhamkulova, B.S., 1969. Antropogenovaya iskopaemaya teriofauna Kazakhstana. Nauka, Alma-Ata, p. 149. + pl. XXXIV. (in Russian).

Kuz'min, Y.V., Orlova, L.A., Zol'nikov, I.D., Igol'nikov, A.E., 2000. The history of mammoth (Mammuthus primigenius Blum.) population in Siberia and adjacent areas (according to radiocarbon data). Russian Geology and Geophysics 41 (5), 723-730.

Laws, R.M., 1966. Age criteria for the African Elephant, Loxodonta a. africana. East African Wildlife Journal IV, 1-37.

Lister, A.M., 1999. Epiphyseal fusion and postcranial age determination in the woolly mammoth Mammuthus primigenius. In: Haynes, G., Klimowicz, J., Reumer, J.W.F. (Eds.), Mammoths and the Mammoth Fauna: Studies of an Extinct Ecosystem (Proceedings of the First International Mammoth Conference, St. Petersburg, Russia, October 16-21, 1995). Deinsea, vol. 6, pp. 79-87.

Lister, A.M. Agenbroad, L.D. 1994. Gender determination of the Hot Springs Mammoths. In: Agenbroad, L.D., Mead, J.I. (Eds.), The Hot Springs Mammoth Site: A Decade of Field and Laboratory Research in Paleontology, Geology, and Paleoecology. The Mammoth Site of Hot Springs, South Dakota, pp. 208-214.

Liu, T.-S., Li, X.-G., 1989. Mammoths in China. In: Martin, P.S., Klein, R.G. (Eds.), Quaternary Extinctions. A Prehistoric Revolution. University of Arizona Press, Tucson, pp. 517-527.

Lyras, G., 2007. Museum labels and fieldnotes. Cranium 24 (2), 45-47.

MacPhee, R.D.E., 2007. Mammoths in the insular Nearctic? Some constrains on the existence of a Pleistocene megafaunal refugium in the Canadian Arctic Archipelago. Quaternary International 169-170, 29-38.

Malez, M., 1986. Die quartären Vertebraten-Faunen in der SFR Jugoslawien. Quartärpaläontologie 6, 101-117.

Markova, A.K., Smirnov, N.G., Kozharinov, A.V., Kazantseva, N.E., Simakova, A.N., Kitaev, L.M., 1995. Late Pleistocene Distribution and diversity of mammals in Northern Eurasia (PALEOFAUNA database). Paleontologica i Evolució 28-29, 5-143.

Markova, A.K., Simakova, A.N., Puzachenko, A.Yu., Kitaev, L.M., 2001. Eastern European mammoth distribution and environments during the Middle Valdai Briansk Interstade (33,000-24,000 BP). In: Cavarretta, G., Gioia, P., Mussi, M., Palombo, M.R. (Eds.), The World of Elephants. Proceedings of the 1st International Congress, Roma, 16-20 Ottobre 2001. Consiglio Nazionale delle Ricerche, Roma, pp. 299-304.

Matsumoto, H., 1937. Two species of mammoths from off Odomari and Vicinity, Karafuto (Saghalin). Zoological Magazine 49 (1), 9-11 (in Japanese, with English summary).

Melentis, J.K., 1961. Die Dentition der pleistozänen Proboscidier des Beckens von Megalopolis im Peloponnes (Griechenland). Annales Géologiques des Pays Helléniques 12, 153-262.

Moreno, A., Cacho, I., Canals, M., Grimalt, J.O., Sánchez-Goñi, M.F., Shackleton, N., Sierro, F.J., 2005. Links between marine and atmospheric processes oscillating on a millennial time-scale. A multi-proxy study of the last 50,000 yr from the Alboran Sea (Western Mediterranean Sea). Quaternary Science Reviews 24, 1623-1636.

Nestares, T., Torres, T., 1998. Un nuevo sondeo de investigación paleoambiental del Pleistoceno y Holoceno en la turbera de Padul (Granada, Andalucía). Geogaceta 23, 99-102.

Nikolov, I., 1969. Nakhodka ot Mammuthus primigenius pri gara Cherepish. Bulgarian Academy of Sciences, Committee of Geology, Bulletin of the Geological Institute. Series Paleontology, vol. 18, pp. 105-110 (in Bulgarian, with English and German summary).

Orlova, L.A., Kuzmin, Y.V., Zolnikov, I.D., 2000. Time-space systematics for mammoths (Mammuthus primigenius Blum.) and prehistoric humans in Siberia (on the basis of radiocarbon dating). Archaeology, Ethnology \& Anthropology of Eurasia 3 (3) 31-41.

Ortiz, J.E., Torres, T., Delgado, A., Julià, R., Lucini, M., Llamas, F.J., Reyes, E., Soler, V., Valle M., 2004. The palaeoenvironmental and palaeohydrological evolution of Padul Peat Bog (Granada, Spain) over one million years, from elemental, isotopic and molecular organic geochemical proxies. Organic Geochemistry 35, 1243-1260.

Palombo, M.R., Alberdi, M.T., Avanza, B., Valli, A.F.M., 2005. Large mammal renewal and elephant spread in the Northwestern Mediterranean Region. In: Agenbroad, L.D. Symington, R.L. (Eds.), 2nd World of Elephants Congress. Short Papers and Abstracts. Mammoth Site of Hot Springs, Hot Springs, pp. 137-141.

Park, S.J., 1988. The palaeoenvironmental changes and macromammal evolution during the Pleistocene in East Asia. Korean Journal of Quaternary Research 2 (1), 51-85.

Pons, A., Reille, M., 1988. The Holocene and Upper Pleistocene pollen record from Padul (Granada, Spain): a new study. Palaeogeography, Palaeoclimatology, Palaeoecology $66(3 / 4), 243-263$.

Poppow, R., 1913. Beitrag zur Kenntnis der Diluvialfauna Bulgariens. Spisanie na Balgarskata Akademija Naukite 7, 115-142.

Porter, S.C., An, Z., 1995. Correlation between climate events in the North Atlantic and China during the last glaciation. Nature 375, 305-308.

Rahmsdorf, S., 2002. Ocean circulation and climate during the past 120,000 years. Nature 419, 207-214.

Roucoux, K.H., de Abreu, L., Shackleton, N.J., Tzedakis, P.C., 2005. The response of NW Iberian vegetation to North Atlantic climate oscillations during the last $65 \mathrm{kyr}$. Quaternary Science Reviews 24, 1637-1653.

Rustioni, M., Ferretti, M.P., Mazza, P., Pavia, M., Varola, A., 2003. The vertebrate fauna from Cardamone (Apulia, southern Italy): an example of Mediterranean mammoth fauna. In: Reumer, J.W.F., de Vos, J., Mol, D. (Eds.), Advances in Mammoth Research. Proceedings of the Second International Mammoth Conference. Rotterdam, 16-20 May 1999. Deinsea, vol. 9, pp. 395-403.

Sala, B., Masini, F., Ficcarelli, G., Rook, L., Torre, S., 1992. Mammal dispersal events in the Middle and Late Pleistocene of Italy and Western Europe. In: Koenigswald, W.v. Werdelin, L. (Eds.), Mammalian Migration and Dispersal Events in the European Quaternary. Courier Forschungsinstitut Senckenberg, vol. 153, pp. 59-68.

Sibuet, J.-C., Monti, S., Loubrieu, B., Mazé, J.-P., Srivastava, S., 2004. Carte bathymétrique de l'Atlantique nord-est et du golfe de Gascogne: implications cinématiques. Bulletin de la Société Géologique de France 175 (5), 429-442.

Stebich, M., Arlt, J., Mingram, J., 2008. Late Quaternary vegetation and climate history of NE China. 12th International Palynological Congress (IPC-XII), 8th International Organisation of Palaeobotany Conference (IOPC-VIII). Abstract Volume, vol. 2008/2. Terra Nostra, p. 265.

Stuart, A.J., Sulerzhitsky, L.D., Orlova, L.A., Kuzmin, Y.V., Lister, A.M., 2002. The latest woolly mammoths (Mammuthus primigenius Blumenbach) in Europe and Asia: a review of the current evidence. Quaternary Science Reviews 21, 1559-1569.

Takahashi, K., Soeda, Y., Izuho, M., Yamada, G., Akamatsu, M., Chang, C.-H., 2006. The chronological record of the woolly mammoth (Mammuthus primigenius) in Japan, and its temporary replacement by Palaeoloxodon naumanni during MIS 3 in Hokkaido (northern Japan). Palaeogeography, Palaeoclimatology, Palaeoecology 233, 1-10.

Takahashi, K., Wei, G., Uno, H., Yoneda, M., Jin, C., Sun, C., Zhang, S., Zhong, B., 2007. AMS ${ }^{14} \mathrm{C}$ chronology of the world's southernmost woolly mammoth (Mammuthus primigenius Blum.). Quaternary Science Reviews 26, 954-957.

Tong, H.-W., 2004. Paleoenvironmental significance of Coelodonta in different fossil assemblages. Acta Anthropologica Sinica 23, 306-314 Supplement, (in Chinese, with English summary).

Turon, J.-L., Lézine, A.-M., Denèfle, M., 2003. Land-sea correlations for the last glaciation inferred from a pollen and dinocyst record from the Portuguese margin. Quaternary Research 59, 88-96.

Ukraintseva, V.V., 1993. Vegetation Cover and Environment of the "Mammoth Epoch" in Siberia. The Mammoth Site of Hot Springs, South Dakota, p. 309.

Vereshchagin, N.K., 1959. Mlekopitayushchie Kavkaza. Istoriya formirovaniya fauny. Izdatelstvo Akademii Nauk SSSR, Moskva, Leningrad, p. 703 (in Russian).

Vereshchagin, N.K., Baryshnikov, G.F., 1980. Mlekopitayushchie predgornogo severnogo Kryma v epokhu paleolita (po kukhonnym ostatkam iz peshcher Chokurcha, Starosele i Mamat-Koba). Trudy Zoologicheskogo Instituta, vol. 93, pp. 26-49 (in Russian).

Viseras, C., Calvache, M.L., Fernández, J., Soria, J.M., 2001. Los abanicos aluviales cuaternarios de la Depresión de Padul (SE de la Cuenca de Granada, Cordillera Bética): Caracterización sedimentaria y geomorfológica. In: Sanz de Galdeano, C. Peláez Montilla, J.A., López Garrido, A.C. (Eds.), La Cuenca de Granada: Estructura, Tectónica activa, Sismicidad, Geomorfología y dataciones existentes, pp. 78-88.

Wang, Y.J., Cheng, H., Edwards, R.L., An, Z.S., Wu, J.Y., Shen, C.-C., Dorale, J.A., 2001. A High-resolution absolute-dated Late Pleistocene monsoon record from Hulu Cave, China. Science 294, 2345-2348.

Webb, S.D., Perrigo, S.C., 1984. Late Cenozoic vertebrates from Honduras and El Salvador: Journal of Vertebrate Paleontology 4 (2), 237-254

West, R.G., 2000. Plant Life of the Quaternary Cold Stages. Evidence from the British Isles. Cambridge University Press, Cambridge, p. 320.

Zhylkibaev, K.Zh., 1975. Drevnie slony Kazakhstana. Izdatelstova Nauka Kazakhskoj SSR, Alma-Ata, p. 132 (in Russian). 